\title{
Upper Wenlock to Lower Př́dolí (Silurian) conodont biostratigraphy of Saaremaa, Estonia, and a correlation with Britain
}

\author{
VIIVE VIIRA ${ }^{1} \&$ RICHARD J. ALDRIDGE ${ }^{2}$ \\ ${ }^{1}$ Institute of Geology, Estonia Avenue 7, EE0105 Tallinn, Estonia. \\ ${ }^{2}$ Department of Geology, University of Leicester, Leicester LE1 7RH, UK.
}

\begin{abstract}
The closely related conodonts Ozarkodina bohemica, $O$. snajdri and $O$. crispa form a clade that provides useful biostratigraphical indices through the upper Silurian. Collections from boreholes and surface outcrops on Saaremaa and from a borehole at Kolka, Latvia, contain new morphotypes of $O$. bohemica and $O$. crispa. A new subspecies, $O$. snajdri parasnajdri, is also distinguished, occurring above $O$. crispa in the Kuressaare and lowermost Kaugatuma stages. Evidence from conodonts and other fossils, primarily chitinozoans, ostracods and ichthyoliths, can be used to correlate the upper Silurian succession of Saaremaa with those of the Welsh Borderland and Gotland, although some problems remain to be solved. The microfossil distribution suggests that there may be a major break at the base of the Ludlow Bone Bed Member at Ludlow, equivalent to the Kuressaare Formation on Saaremaa. J. Micropalaeontol. 17(1): 33-50, April 1998
\end{abstract}

\section{INTRODUCTION}

The study of the Silurian rocks of Estonia dates back to the last century, with the establishment of a Lower Palaeozoic stratigraphical scheme by Schmidt (1858). Details were added in the earlier part of this century, and more recently scientific investigations have been considerably advanced by a group of researchers at the Institute of Geology, Estonian Academy of Sciences, working under the leadership of D. Kaljo. Modern research has been greatly facilitated by the availability of numerous boreholes drilled by the Estonian Geological Survey, and a large number of papers and monographs has been published on Lower Palaeozoic palaeontology, stratigraphy and facies distribution. General summaries of the main results of this work may be found in volumes edited by Kaljo $(1970,1977)$, Kaljo \& Klaamann $(1982 a, b)$ and Kaljo \& H. Nestor (1990).

The current understanding of the Silurian stratigraphy of Estonia has been summarised by H. Nestor (1993) and the Wenlock-Přídoli correlation chart is shown in Fig. 1. The main stratigraphical units are regional chronostratigraphical stages, within which separate local lithostratigraphical units are distinguished in different parts of the Baltic basin (Bassett et al., 1989). The local units reflect facies differences: Central Estonia and most of Saaremaa (Fig. 2) are dominated by shallow-water facies, whereas in South Estonia and on the Sörve Peninsula of southern Saaremaa deeper water shelf and outer shelf sediments prevail (H. Nestor \& Einasto, 1977; Bassett et al., 1989). Gradual shifts of the facies belts occurred during the evolution of the basin.

The present paper deals with the succession representing the late Wenlock to early Př́idolí interval, embracing the Rootsiküla, Paadla, Kuressaare and Kaugatuma stages. In the absence of graptolites, the correlation of these stages and their representative formations with other areas is currently only approximate. The Rootsiküla Formation is considered to correspond to the late Wenlock Klinte Secundo Episode of Jeppsson et al. (1995), when very variable shallow-water sediments were deposited with characteristic cyclic alternation of limestones and primary dolomites. The total thickness is $25-32 \mathrm{~m}$, and the sediments display frequent discontinuity surfaces, mud cracks, ripple marks and trace fossils. Abundant stromatolites and oncolites occur, but the fauna is restricted to eurypterids, thelodonts and conodonts. The Paadla Formation is 26-32 $\mathrm{m}$ thick and consists of detrital biomorphous and biohermal stromatoporoid-coral limestones, dolomites and marls. A hiatus beneath the base, established from chitinozoan data, has been reported to eliminate almost all local equivalents of the lower Ludlow Gorstian Stage in parts of the region (Nestor, V., 1982, 1990). The Kuressaare Formation comprises a broadly similar range of lithologies to those found in the Paadla, but there is a rich fauna that includes ostracods and thelodonts, both of which have proved useful in local correlations. Published conodont data are currently limited, with more precision required on the ranges of key taxa (Kaljo, 1990). Indirect correlation suggests that the Kuressaare Stage is at the level of the formosus/balticus standard graptolite biozone (Kaljo, 1990).

In this contribution, we present details of the distribution of key conodont species in exposed sections and borehole cores on the island of Saaremaa, Estonia, and in a borehole from Kolka, Latvia (Fig. 2). The evolving species complex comprising taxa referred to Ozarkodina bohemica (Walliser), O. snajdri (Walliser) and $O$. crispa (Walliser) is of particular importance, and this group is given especial attention. The conodont data are used in conjunction with information from other fossils to assess the correlations between the Estonian succession and those of Britain and other areas.

\section{BACKGROUND TO CONODONTS}

\section{The Ozarkodina bohemica lineage}

The oldest reported member of this lineage is $O$. bohemica subsp. nov. of Aldridge (1985, pl. 3.3, figs $13 \mathrm{a}, \mathrm{b}$ ), from the lowermost Wenlock of Whitfield, Gloucestershire, England. Above this, there is a gap in records until well into the Homerian Stage (upper Wenlock), where $O$. bohemica bohemica is widely distributed. Ludlow representatives of the same lineage include $O$. snajdri, which appears in the upper part of the Gorstian Stage, and $O$. crispa, of latest Ludlow age; these two were 


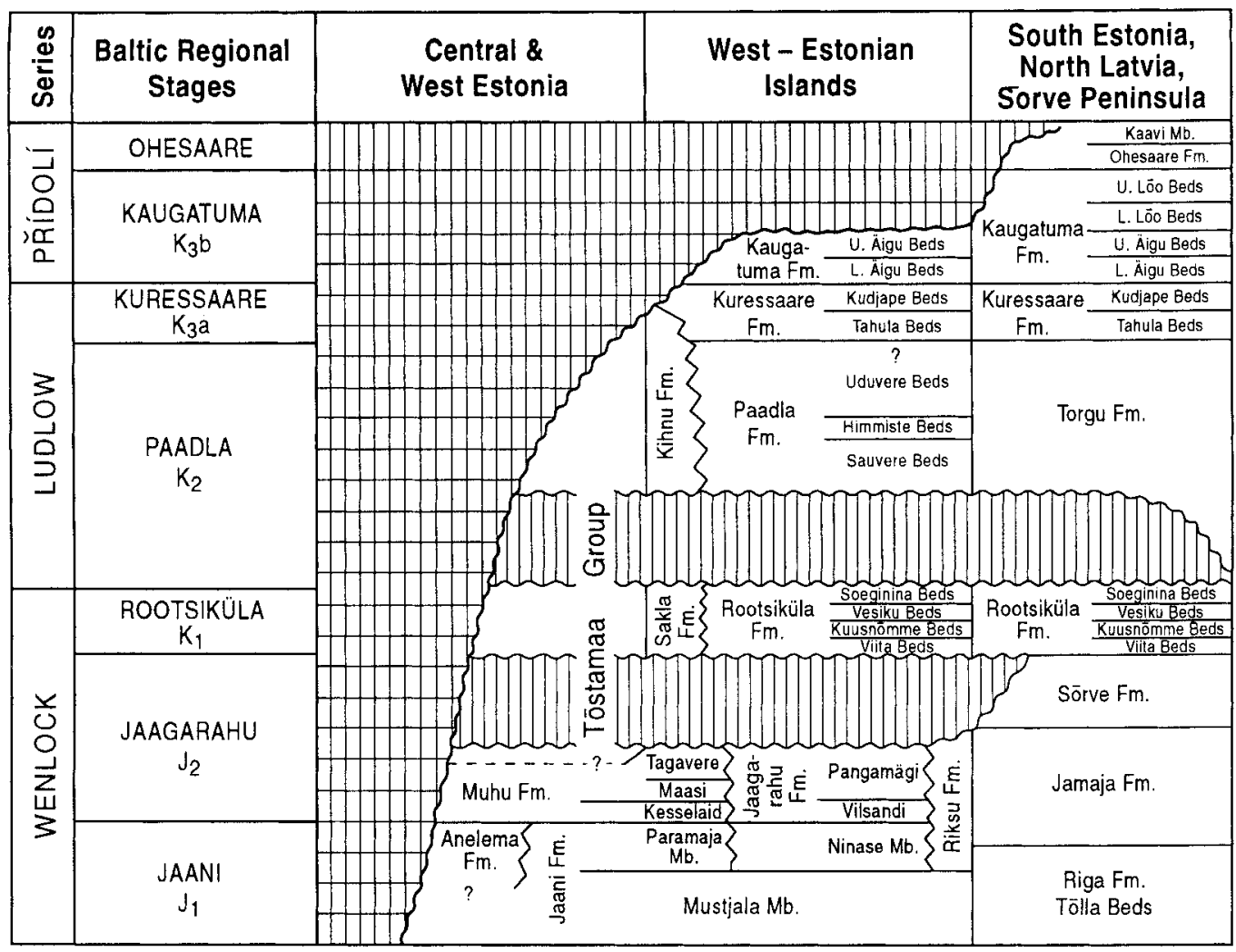

Fig. 1. Current correlation chart of Wenlock-Př́doli stratigraphical units in Estonia and Latvia (from Nestor, 1993).

considered to be important fossils by Walliser (1964) in his conodont biozonation of the Silurian.

Early views of the relationships of these species varied. Walliser (1964) included $O$. bohemica as a subspecies of $O$. sagitta (Walliser) and commented that $O$. snajdri may be a descendant of $O$. excavata (Branson \& Mehl). Pollock \& Rexroad (1973) suggested that $O$. snajdri was ancestral to $O$. remscheidensis eosteinhornensis (Walliser), or that they shared common ancestry, and Mehrtens \& Barnett (1976) also considered $O$. snajdri to be the ancestor of $O$. eosteinhornensis. Helfrich (1975) used morphological characteristics of $\mathrm{Pa}$ elements and multielement patterns to identify a 'Spathognathodus sagitta bohemicus Lineage' which incorporated taxa that would now be referred to as $O$. bohemica bohemica, $O$. bicornuta (Helfrich), $O$. snajdri, $O$. tillmani (Helfrich), $O$. crispa and, tentatively, his N. gen. et n. sp. (Helfrich, 1975, pl. 16, figs 1-3, 6). The latter has subsequently been described as Homeognathodus peniculus (Denkler \& Harris, 1988). Helfrich (1975) recorded that all $\mathrm{Pa}$ elements of this lineage posess a basal cavity of similar form which closes before the posterior tip of the blade in stratigraphically older forms but extends further posteriorly relative to the posterior blade in successively younger species. A further characteristic of all the Pa elements, except that of $O$. bicornuta, is a tendency towards fusion of denticles above the basal cavity.

Aldridge \& Schönlaub (1989) stated that $O$. crispa was a direct descendant of $O$. snajdri, and that the two occurred in stratigraphical succession. Miller (1995) agreed that $O$. crispa originated in $O$. snajdri, but showed that intermediate forms occurred in the Welsh Borderland at stratigraphically higher levels than the first occurrence of $O$. crispa, so the relationship was not one of simple phyletic transition.

The succession of these conodonts on Saaremaa is comparable with that identified by Helfrich (1975). Ozarkodina bohemica bohemica, $O$. aff. bicornuta, $O$. snajdri snajdri and $O$. crispa are all recognized, and some specimens of $O$. crispa are transitional to $O$. tillmani. The youngest representatives, above the last occurrence of $O$. crispa, are clearly of snajdri affinities and are here referred to as $O$. snajdri parasnajdri subsp. nov.

\section{Previous records of $O$. snajdri and $O$. crispa}

The holotype of $O$. snajdri is from Muslovka Quarry, Bohemia, a few metres below the base of the ultimus graptolite biozone, while that of $O$. crispa is from Santa Creu, Spain (Walliser, 1964). In his conodont biozonation, Walliser (1964) included a 'crispus zone' in the uppermost Ludlow, and a 'snajdri-Horizon' within the upper part of the middle/upper Ludlow siluricus zone; $O$. crispa was represented in samples from his reference section at Cellon in the Carnic Alps, whereas O. snajdri was not.

Subsequent records produced some uncertainties about the ranges of $O$. snajdri, $O$. crispa and the index taxon of the zone succeeding the 'crispus zone', $O$. r. eosteinhornensis. Fàhraeus (1969) reported the Pa element of $O$. crispa on Gotland in strata above O.r. eosteinhornensis, leading Walliser (1971) to question 


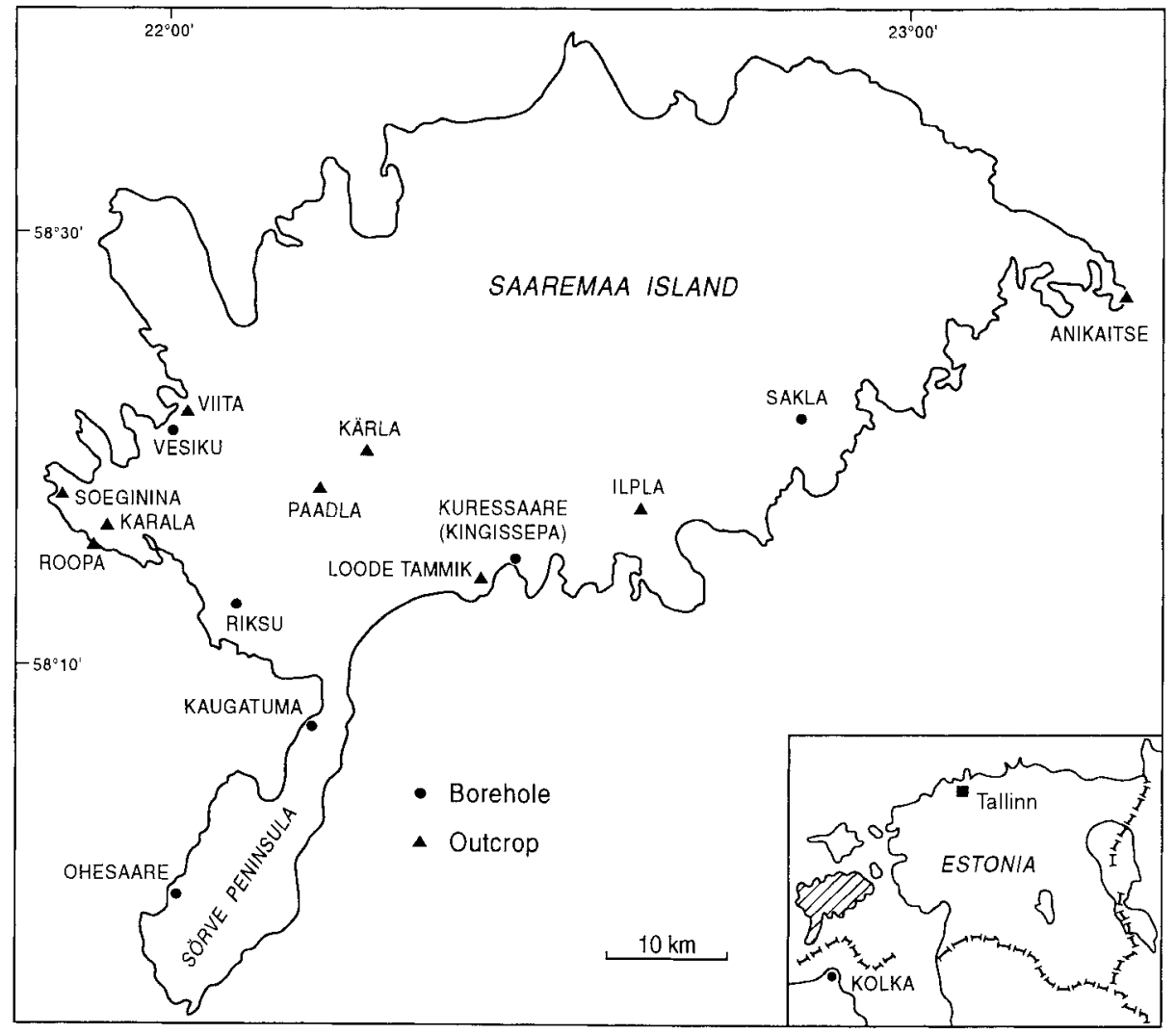

Fig. 2. Location map of outcrops (triangles) and boreholes (circles) on Saaremaa and northernmost Latvia.

whether the 'crispus zone' lay within the 'eosteinhornensis zone' or whether the two overlapped. In fact, the specimen illustrated by Făhraeus (1969, pl. 2, figs 13, 14) may belong to $O$. snajdri, although subsequent work has resulted in records of $O$. crispa and representatives of the steinhornensis group in association on Gotland (Jeppsson, 1983; Jeppsson et al., 1994) An association of $O$. snajdri with specimens referred to as primitive $O . r$. eosteinhornensis was reported by Rexroad \& Craig (1971) in the Bainbridge Formation of Lithium, Missouri, and the two taxa were also recorded together in the Kokomo Limestone Member of the Salina Formation in north-central Indiana by Pollock \& Rexroad (1973). The specimens illustrated by Pollock \& Rexroad (1973, pl. 1, figs 30-34), however, show several characteristics of the $\mathrm{Pa}$ element of $O$. crispa and the specific assignment is equivocal. An overlap of the ranges of $O$. crispa and specimens referred to $O$. r. eosteinhornensis in North America was also found by Helfrich (1975) in the Central Appalachians, while Denkler \& Harris (1988) reported that the range of $O$. snajdri in the same region began below that of $O$. crispa and terminated above it.

In Australia, De Deckker (1976) found some overlap of the ranges of $O$. snajdri and $O$. crispa in the Kildrummie Formation of New South Wales, and was the first to suggest that the range of $O$. snajdri might be longer than previously thought. He also considered a second possibility that the intraspecific variation of $\mathrm{Pa}$ elements of $O$. crispa may include specimens of similar morphology to $O$. snajdri. However, his specimens are rather atypical, and resemble those described by Link \& Druce (1972, pl. 9, figs 22-28) from the Yass Basin, New South Wales as Spathognathodus cf. $S$. ranuliformis Walliser, a species that is now assigned to the genus Kockelella.

In Europe, there are records of overlap between $O$. snajdri and $O$.r. eosteinhornensis s. 1 . in sections near Graz, Austria (Ebner, 1976) and in the uppermost Kopanina Formation of Pozarech Quarry, Bohemia (Mehrtens \& Barnett, 1976). Feist \& Schönlaub (1974) found $O$. crispa, O. r. eosteinhornensis s. 1. and Pedavis latialatus (Walliser) together in the Montagne Noire, southern France, and Chlupác et al. (1980) demonstrated the overlap of $O$. crispa and $O$. r. eosteinhornensis s. 1 . in the Muslovka Quarry, Bohemia, leading to a proposal to incorporate a crispa subzone within the lower part of an extended eosteinhornensis zone. Chlupác et al. (1980) also showed an overlap in the ranges of $O$. snajdri and $O$. crispa in Kolednik Quarry, Bohemia. In Britain, uppermost Ludlow conodont faunas include $O$. snajdri, $O$. cf. snajdri, $O$. crispa, $O$. cf. crispa, $O$. r. eosteinhornensis s. 1. and $O$. remscheidensis baccata Miller \& Aldridge (Miller, 1995; Miller \& Aldridge, 1997). In two sections, at Woolhope and at Tite's Point, Miller (1995) found $O$. snajdri above $O$. crispa.

In summary, all possibilities of co-occurrence of $O$. snajdri, $O$. crispa and specimens referred to $O, r$. eosteinhornensis are known; all three may occur together or any pairing. Only in 
Bohemia are they represented in clearly succeeding order, in the Muslovka and Kolednik quarries, and even here there is some overlap of the ranges.

\section{SYSTEMATIC DESCRIPTIONS}

Systematics are given here for members of the $O$. bohemica lineage, based on material from Saaremaa. As noted by Miller \& Aldridge (1997), there is some inconsistency regarding the usage of subspecies and morphotype designations in conodont taxonomy. We have followed the principle of retaining subspecies designations for populations that are separated in space and/or time; for morphological variants that occur together in some samples we have used morphotypes. The exceptions are where we subdivide subspecies or exisiting morphotypes: even if different forms seem to be chronologically or geographically separated, we have designated them as morphotypes.

Order Ozarkodinida Dzik, 1976

Family Spathognathodontidae Hass, 1959

Genus Ozarkodina Branson \& Mehl, 1933

Ozarkodina bohemica bohemica (Walliser, 1964)

1964 Spathognathodus sagitta bohemicus Walliser: 83, pl. 7, fig. 4 , pl. 18 , figs 23,24

1964 Ozarkodina edithae Walliser: 55, pl. 26, figs 12-18.

1967 Spathognathodus sagitta bohemicus Walliser; Austin \& Bassett: 278, pl. 14, fig. 19.

1967 Spathognathodus cf. sagitta bohemicus Walliser; Austin \& Bassett: 279, pl. 14, fig. 20.

?1967 Spathognathodus sagitta bohemicus Walliser; Flajs: pl. 4, fig. 7.

1969 Spathognathodus sagitta bohemicus Walliser; Fåhraeus: pl. 2, figs $15,16$.

1975 Spathognathodus sagitta bohemicus Walliser; Helfrich: pl. 1, figs $2-4,8,12,17,20$.

1975a Ozarkodina sagitta bohemica (Walliser); Aldridge: $327, \mathrm{pl}$. 47, fig. 21.

1975b Ozarkodina sagitta bohemica (Walliser); Aldridge: pl. 2, figs 18,19

1976 Ozarkodina sagitta bohemica (Walliser); Barrick \& Klapper: 81, pl. 4, figs 1-7, 10, 12.

1981 Ozarkodina sagitta bohemica (Walliser); Aldridge, Dorning \& Siveter: pl. 2.3, figs 1, 3 .

1982a Spathognathodus sagitta bohemica Walliser; Viira: text-fig. 5.4, figs 31,34 .

1984 Ozarkodina sagitta bohemica (Walliser); Kozur: pl. 2, figs 4, 5.
1985 Ozarkodina sagitta bohemica (Walliser); Balogh \& Kozur: pl. 2 , fig. 5 .

1985 Ozarkodina bohemica bohemica (Walliser); Aldridge: pl. 3.4, fig. 3.

1985 Spathognathodus sagitta bohemicus Walliser; Qiu: 32, pl. 2, figs 1-4.

1985 Spathognathodus sagitta bohemicus Walliser; Yu: 26, pl. 2, figs 1,2 , pl. 3, figs $1-3,6,11$.

1987 Ozarkodina sagitta bohemica (Walliser); An: 200, pl. 32, figs 21, 22.

1990 Ozarkodina bohemica (Walliser); Kleffner: fig. 3, no. 20.

1990 Ozarkodina tillmani (Helfrich); Kleffner: fig. 3, nos 21, 22.

1993 Ozarkodina bohemica (Walliser), Morphotype 1; Schönlaub

(In Kríz et al.): 829, pl. 1, figs 1, 3, 4.

?1993 Ozarkodina bohemica (Walliser), Morphotype 2; Schönlaub (In Kríz et al.): 829, pl. 1, fig. 9.

1993 Ozarkodina bohemica (Walliser), Morphotype 3; Schönlaub (In Kríz et al.): 829, pl. 1, figs 10-14.

Diagnosis. See Aldridge (1985, p. 88).

Remarks. Three morphotypes of $O$. b. bohemica were distinguished by Schönlaub (In Kriz et al., 1993) and numbered 1-3; morphotype 1 has low posterior denticles, similar to $O$. sagitta, whereas morphotype 3 has an abrupt posterior termination and a widely flaring basal cavity. Morphotype 2 is very distinct, with an ornament of ridges of fused denticles on the basal cup. Schönlaub did not mention the specimens originally described by Walliser (1964), with a widely flaring basal cavity extending to the posterior tip, but they appear to be closest to morphotype 3. Because we cannot relate Walliser's specimens or ours to the Bohemian morphotypes we apply a different notation here. The type specimen and associates represent the $\alpha$ morph. Those from Saaremaa have a less flared cavity which does not extend right to the posterior tip and belong to the $\beta$ morph.

Ozarkodina bohemica bohemica $\beta$ morph (P1. 1, figs 1-15)

Description. $\mathrm{Pa}$ element: blade long, with 14-20 denticles that are largest posteriorly. Anterior edge gently convex, posterior edge upright. Basal cavity situated beneath posterior part of blade, terminating short of posterior tip. Small specimens shorter and relatively higher than large specimens. Large specimens usually with fused denticles above basal cavity and a longitudinal ledge in the lower third of the blade. All specimens with white matter, deep above basal cavity and narrowing anteriorly and posteriorly so that extreme denticles may be hyaline.

Occurrence on Saaremaa. Rootsiküla Stage: Vesiku borehole

\section{Explanation of Plate 1}

Figured specimens on all plates are Pa elements; they are deposited in the Institute of Geology, Estonian Academy of Sciences, Tallinn. figs 1-15. Ozarkodina bohemica bohemica (Walliser 1964) $\beta$ morph, Rootsiküla Formation. figs 1, 9, 11, 15; lateral views, Cn 1454-Cn 1457, $\times 120, \times 50, \times 80$, $\times 65$, Viita Beds, Ohesaare borehole, $145.55 \mathrm{~m}$. figs 2, 3; lateral and aboral views, $\mathrm{Cn} 1458, \times 50$, Viita Beds, Ohesaare borehole, 142.25 m. figs 4-6, 10; lateral, lower lateral, aboral and oral views, Cn 1459, $\times 50, \times 50, \times 135, \mathrm{Cn} 1460$, x50, Viita Beds, Kaugatuma borehole, 100.25 m. figs 7, 8; lateral and aboral views, Cn 1461, $\times 50, \times 85$, Viita Beds, Ohesaare borehole, $144.05 \mathrm{~m}$. fig. 12; lateral view, Cn 1462, $\times 55$, Viita Beds, Vesiku borehole, $4.95 \mathrm{~m}$. fig. 13; lateral view, Cn 1463, $\times 55$, Viita Beds, Viita outcrop. fig. 14; lateral view, Cn 1464, $\times 70$, Vesiku Beds, Kaugatuma borehole, $81.4 \mathrm{~m}$. figs 1619. Ozarkodina aff. bicornuta (Helfrich 1975). figs 16, 17; lateral views, Cn 1465, Cn 1466, $\times 65, \times 75$, Soeginina Beds, Soeginina cliff, sample 3-87. fig. 18; lateral view, Cn 1467, $\times 85$, lowermost Paadla Formation, Anikaitse outcrop, sample 4-76. fig. 19; lateral view, Cn 1468, $\times 80$, Soeginina Beds, Soeginina cliff, sample 2-87. figs 20, 21. Ozarkodina snajdri cf. snajdri (Walliser 1964). fig. 20; lateral view, Cn 1469, $\times 80$, Torgu Formation, Ohesaare borehole, $113.35 \mathrm{~m}$. fig. 21, lateral view, Cn 1470, $\times 75$, Kuressaare Formation, Kolka borehole, $284.2 \mathrm{~m}$. 


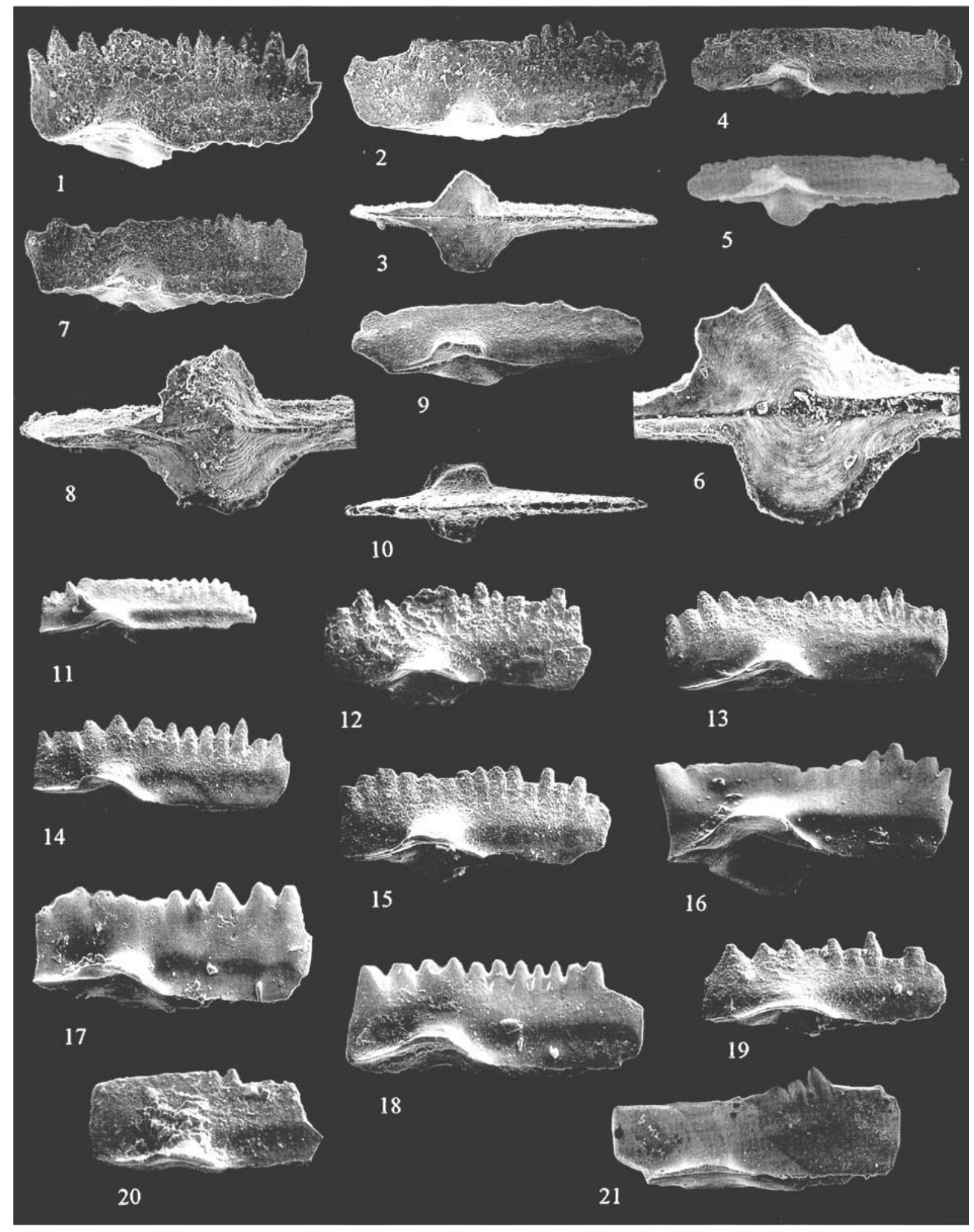

Plate 1 


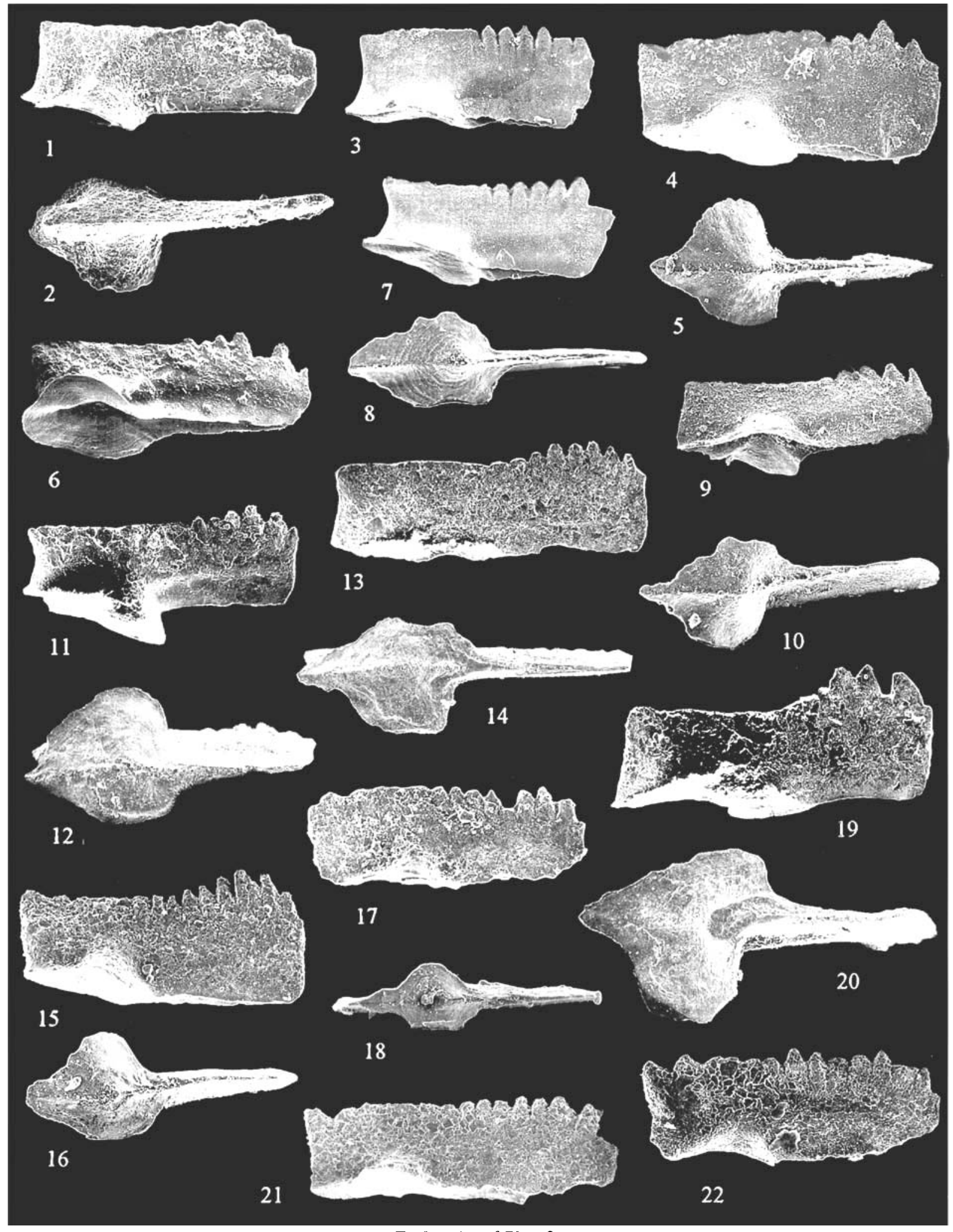

Explanation of Plate 2

Figs 1-16, 19, 20. Ozarkodina crispa (Walliser 1964) $\alpha_{2}$ morph. figs 1,2 ; lateral and oral views, Cn $1471, \times 70$, Sauvere Beds, Kaugatuma borehole, $61.6 \mathrm{~m}$. figs 3, 7, 8; lateral and aboral views, Cn 1472, Cn 1473, $\times 70, \times 85$, Kudjape Beds, Kolka borehole, 270.8 m. figs 4, 5; lateral and aboral views, Cn 1474, $\times 85$, Sauvere Beds, Riksu borehole, 33.5 m. Fig. 6; lower lateral view, Cn 1475, $\times 75$, Himmiste Beds, Kaugatuma borehole, 58.5 m. figs 9, 10; lateral and aboral views, Cn 1476, ×70, $\times 85$, Sauvere Beds, Riksu borehole, $35.0 \mathrm{~m}$. figs 11-16, 19, 20; lateral and aboral views, Cn 1477- Cn $1480, \times 65, \times 85, \times 70, \times 90$, Himmiste Beds, Karala outcrop. figs 17, 18, 21, 22. Ozarkodina crispa (Walliser 1964) $\alpha_{3}$ morph; lateral and aboral views, Cn $1481-$ Cn 1483, $\times 85, \times 70, \times 85$, Himmiste Beds, Karala outcrop. 
$4.95 \mathrm{~m}$, Sakla borehole 51.86-54.45 m, Kaugatuma borehole 81.4-100.25 m, Ohesaare borehole 142.25-157.2 m, Kolka borehole $362.3 \mathrm{~m}$, Viita outcrop.

Material. Pa element: 44 specimens.

\section{Ozarkodina aff. bicornuta (Helfrich, 1975)}

(P1. 1, figs 16-19)

aff. 1975 Spathognathodus bicornutus Helfrich: pl. 1, figs 5-7, 11, 13-16, 18, pl. 2, figs 1, 4, 6, 16 .

Description. Pa element: specimens small; blade rather high, denticles wide, usually 10-11 when not fused. Basal cavity beneath posterior part of blade, circular, not extending to posterior tip. Morphologically close to the smallest specimen illustrated by Helfrich (1975, pl. 1, fig. 5).

Remarks. The specimens illustrated by Helfrich (1975) are very variable, but most have a single high denticle at both ends of the blade; between these are 5-10 denticles which show no fusion on any of the figured specimens. The Estonian specimens have an enlarged posteriormost denticle, but the anterior denticle is not markedly different in size from its neighbours; the denticles above the cavity may be fused.

Occurrence. Uppermost Rootsiküla Stage: Soeginina samples 13, Anikaitse sampes 4, 8 .

Material. Pa element: 9 specimens.

Ozarkodina crispa (Walliser, 1964)

1964 Spathognathodus crispus Walliser: 74, pl. 9, fig. 3, pl. 21, figs 7-13.

?1969 Spathognathodus crispus Walliser; Fåhraeus: pl. 2, figs 13, 14.

1971 Spathognathodus crispus Walliser; Bultynck \& Pelhate: pl. 1 , figs 19, 20.

1971 Spathognathodus crispus Walliser; Drygant: 782, figs 1-3.

1974 Spathognathodus crispus Walliser; Feist \& Schönlaub: pl. 7, figs $8,9,11,12,14,15$.

1974 Ozarkodina crispa (Walliser); Klapper \& Murphy: 33, pl. 8, fig. 10.

1975 Spathognathodus crispus Walliser; Helfrich: pl. 14, figs 1-4, 9, 14, 19, 21, 24, 27.

1977 Ozarkodina crispa (Walliser); Cooper: 188, pl. 16, figs 16, 17.

1980 Ozarkodina crispa (Walliser); Chlupác et al:: pl. 25, figs 1215.

1980 Spathognathodus crispus Walliser; Wang: 374 , pl. 1, figs 13, 14-16, 19-21, 24, 25, text-fig. 4 .

1984 Ozarkodina crispa (Walliser); Kozur: pl. 4, fig. 4.

1984 Spathognathodus crispus Walliser; Drygant: 126, pl. 10, figs $12,13$.

1985 Ozarkodina crispa (Walliser); Balogh \& Kozur: pl. 3, fig. 3. 1986 Spathognathodus crispus Walliser; Jiang et al.: pl. 4-4, fig. 9. 1987 Spathognathodus crispus Walliser; An: 202, pl. 34, figs 20 , 21.

1988 Ozarkodina snajdri crispa (Walliser); Denkler \& Harris: pl. 1 , figs $\mathrm{J}, \mathrm{K}$.

1989 Ozarkodina crispa (Walliser); Walliser \& Wang: 114, textfig. 1, pl. 1, figs 1-16.

1990 Ozarkodina aff. snajdri (Walliser); Männik \& Viira: pl. 18, fig. 10.

1990 Ozarkodina crispa (Walliser) $\beta$ morphotype; van den
Boogaard: 11, pl. 6, figs 2-7.

1994 Ozarkodina aff. snajdri crispa (Walliser); Viira: pl. 1, fig. 8. 1994 Ozarkodina snajdri (Walliser); Jeppsson et al.: fig. 4d.

1995 Ozarkodina crispa (Walliser); Miller: pl. 3, figs 1-2, 4-5. 1995 Ozarkodina cf. crispa (Walliser); Miller: pl. 3, figs 3, 6-12 Remarks. $\mathrm{Pa}$ elements that have been assigned to $O$. crispa show considerable variation, and four morphotypes, designated $\alpha, \beta$, $\chi, \delta$, were differentiated by Walliser \& Wang (1989). The $\beta, \chi$ and $\delta$ morphs are all characterized by a furrow on the oral margin of the blade; the $\alpha$ morph lacks the furrow. The holotype selected by Walliser (1964, pl. 21, fig. 12) lacks a furrow and thus belongs to the $\alpha$ morph, as do all the specimens from the northern East Baltic. However, there is major variation within this group, and we distinguish $\alpha_{1}, \alpha_{2}$ and $\alpha_{3}$ morphs, with the holotype belonging to $\alpha_{1}$.

\section{Ozarkodina crispa $\alpha_{2}$ morph}

(P1. 2, figs 1-16, 19, 20, Pl. 3, figs 5, 6, 9-11)

Description. Pa element: specimens small; blade high, short with fused denticles towards posterior end. Denticle height decreases posteriorly from anterior end to fused portion. Posterior termination of blade concave to vertical. Basal cavity with wide subcircular lips, underlying posterior half of blade and extending to posterior tip. White matter fills denticles, extending down to tip of cavity beneath fused portion of blade.

Remarks. These specimens differ from the $\alpha_{1}$ morph in the subcircular, rather than asymmetrical, shape of the basal cavity. Occurrence on Saaremaa. Paadla Stage and lowermost Kuressaare Stage: Sakla borehole $18.0-33.13 \mathrm{~m}$, Riksu borehole $35.0 \mathrm{~m}$, Kaugatuma borehole $49.7-69.3 \mathrm{~m}$, Ohesaare borehole 99.75-100.8 m, Kolka borehole 270.8-284.2 m; Kärla, Roopa, Paadla and Karala outcrops.

Material. Pa element: more than 100 specimens.

$$
\text { Ozarkodina crispa } \alpha_{3} \text { morph }
$$

\section{(PI. 2, figs 17, 18, 21, 22, Pl. 3, figs $1-4,7,8$ )}

Description. Pa element: similar to $\alpha_{2}$ morph but with posterior denticles unfused or only partly fused. Basal cavity variable in position, normally extending to posterior tip. White matter occupies one-third to one-half of blade.

Remarks. Specimens in which the basal cavity does not extend beyond the posterior end of the blade are similar to O.s. snajdri, but differ in the smaller size of the cavity and the shorter blade. The specimens illustrated by Helfrich (1975) encompass the range of variation shown by $\alpha_{2}$ and $\alpha_{3}$ morphs.

Occurrence on Saaremaa. Paadla Stage and lowermost Kuressaare Stage: Sakla borehole $30.15 \mathrm{~m}$, Riksu borehole 33.5 $35.0 \mathrm{~m}$, Kuressaare (Kingissepa) borehole $39.14 \mathrm{~m}$, Ohesaare borehole $100.8 \mathrm{~m}$, Kolka borehole 276.15-284.2 m; Roopa and Karala outcrops.

Material. Pa element: 31 specimens.

Ozarkodina snajdri (Walliser 1964)

1964 Spathognathodus snajdri Walliser: 84, pl. 9, fig. 2, pl. 21, figs 14-15, pl. 22, figs 1-4.

?1969 Spathognathodus crispus Walliser; Fåhraeus: pl. 2, figs 13, 14.

?1969 Spathognathodus cf. snajdri Walliser; Schönlaub: pl. 1, fig. 29. 


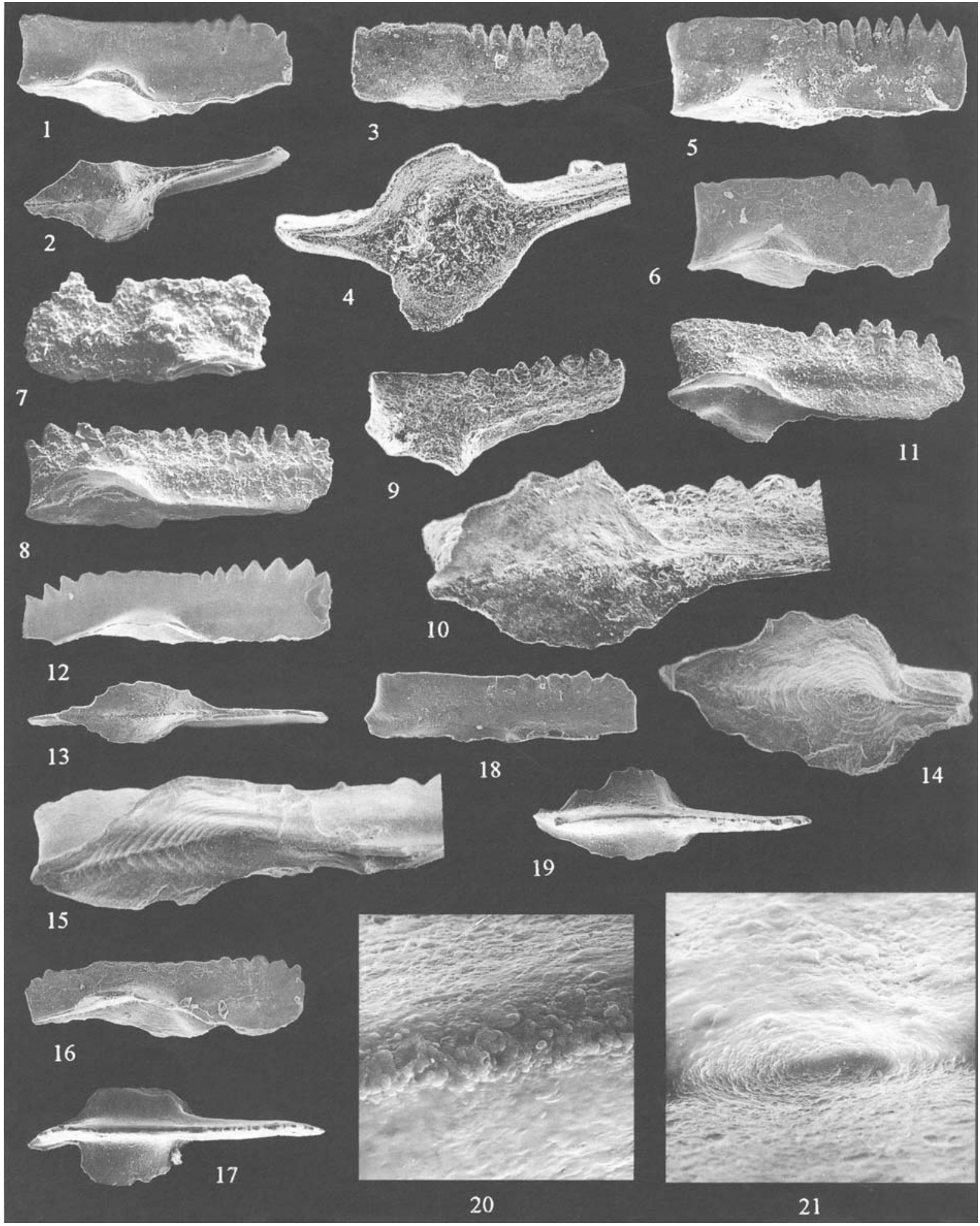

Explanation of Plate 3

Figs 1-4, 7, 8. Ozarkodina crispa (Walliser 1964) $\alpha_{3}$ morph. figs 1-4; lateral and aboral views, Cn 1484, Cn 1485, $\times 70, \times 85, \times 150$, Sauvere Beds, Sakla borehole, $30.15 \mathrm{~m}$. fig. 7; lateral view, Cn 1486, $\times 80$, Sauvere Beds, Kèrla outcrop. fig. 8; lateral view, Cn 1487, $\times 85$, Himmiste Beds, Roopa cliff. figs 5, 6, 9-11. Ozarkodina crispa (Walliser 1964) $\alpha_{2}$ morph. fig. 5; lateral view, Cn 1488, $\times 85$, Sauvere Beds, Sakla borehole, $30.15 \mathrm{~m}$. fig. 6; lateral view, Cn 1489, $\times 85$, Uduvere Beds, Sakla borehole, 18.0 m. figs 9-11; lateral and aboral views, Cn 1490, Cn 1491, $\times 70, \times 150, \times 95$, Himmiste Beds, Paadla outcrop, sample 3-73. figs 12-21. Ozarkodina snajdri parasnajdri subsp. nov. figs 12, 13; lateral and aboral views, Cn 1492, $\times 50$, Äigu Beds, Ohesaare borehole, 67.4 m. Figs 14, 16; aboral and lateral views, Cn 1493, Cn 1494, $\times 120, \times 50$, Äigu Beds, Ohesaare borehole, $64.65 \mathrm{~m}$. figs 15,17 ; lower lateral and oral views, Cn 1495, Cn 1496, $\times 120, \times 45$, Äigu Beds, Ohesaare borehole, $61.2 \mathrm{~m}$. figs 18-21, lateral and oral views, oral views of fused denticles and a discrete denticle, Cn 1497, ×50, ×850, Äigu Beds, Ohesaare borehole, $67.4 \mathrm{~m}$. 


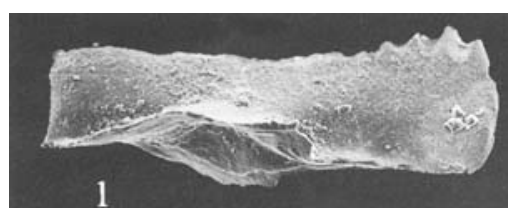

1

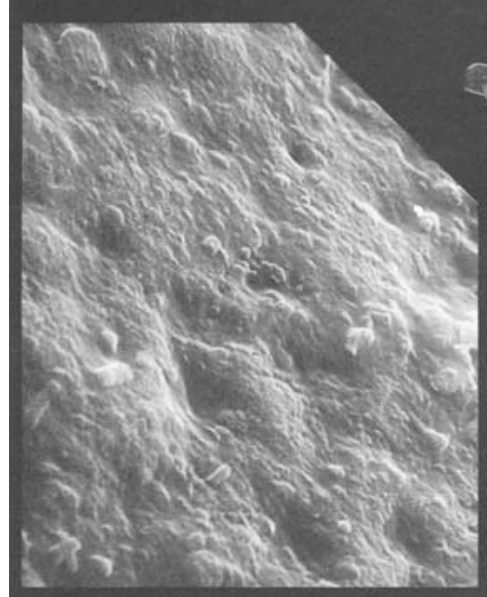

2

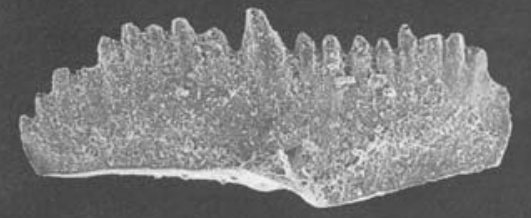

11

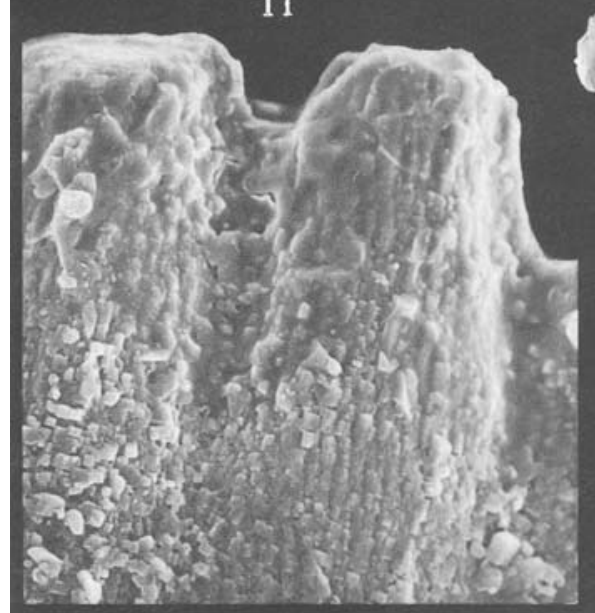

12

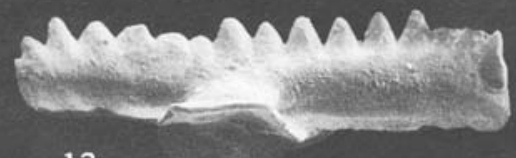

13
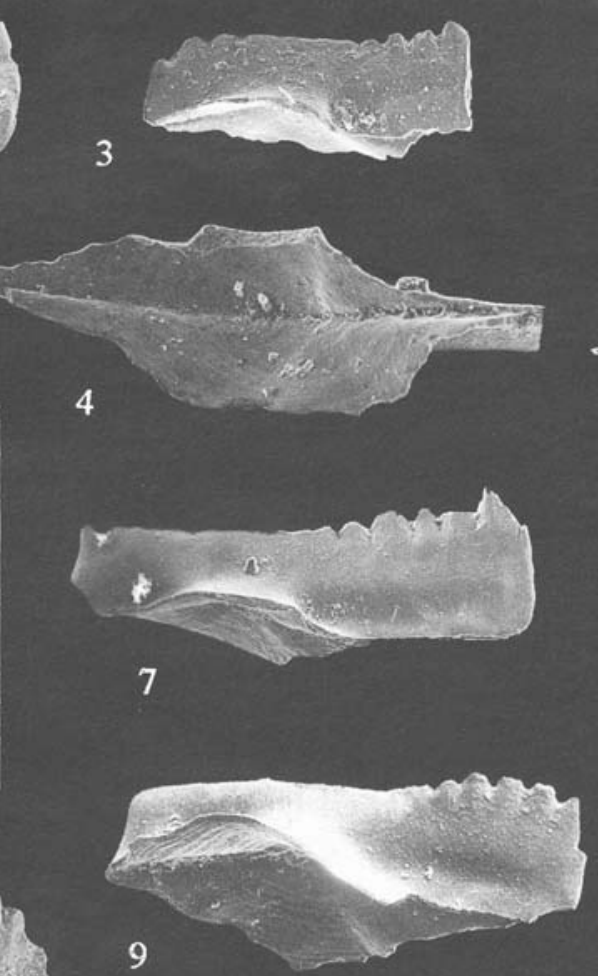

9

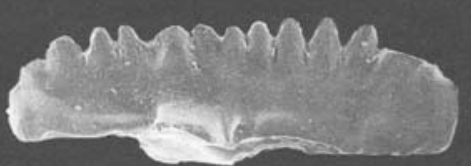

14

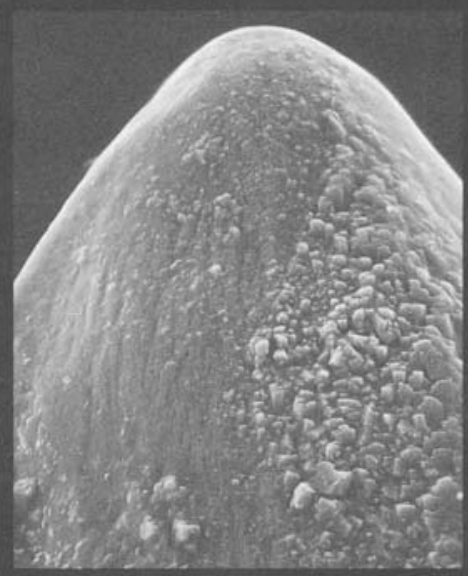

16
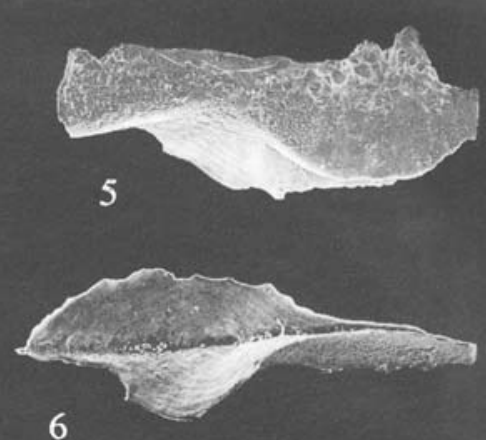

6
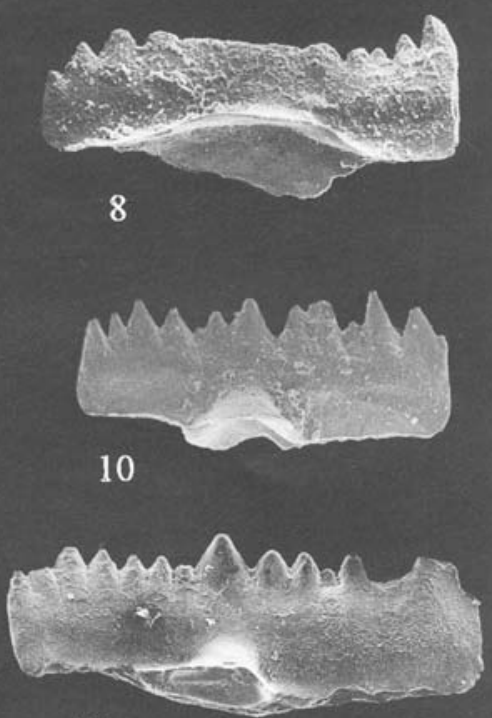

15

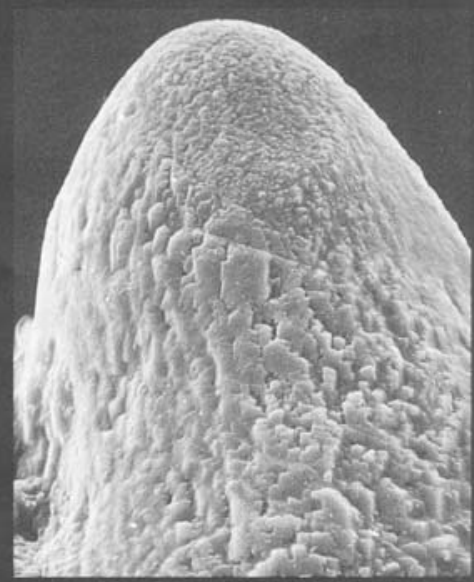

17

Explanation of Plate 4

Figs 1-9. Ozarkodina snajdri parasnajdri subsp. nov. figs 1, 2; lateral view, Cn 1498, $\times 50$, detail $\times 2600$, Äigu Beds, Kolka borehole, $263.4 \mathrm{~m}$. figs 3,4 ; lateral and aboral views, Cn 1499, Aigu Beds, Kolka borehole, $263.4 \mathrm{~m}$. Figs 5, 6, 8; lateral and aboral views, Cn 1500, Cn 1501, $\times 85, \times 95, \times 50$, Kuressaare Formation, Ilpla outcrop. fig 7; lateral view, Cn 1502, $\times 50$, Äigu Beds, Kolka borehole, $264.4 \mathrm{~m}$. fig. 9; lower lateral view, Cn 1503, $\times 45$, Tahula Beds, Kaugatuma borehole, $45.5 \mathrm{~m}$. figs 10, 13-17. Ozarkodina remscheidensis eosteinhornensis (Walliser 1964) sensu lato. fig. 10; lateral view, Cn 1505, ×40, Kaugatuma Formation, Ohesaare borehole, $58.7 \mathrm{~m}$. fig. 13; lateral view, Cn 1506, $\times 40$, Kuressaare Formation, Vaivere outcrop. fig. 14; lateral view, $\times 50$, Kaugatuma Formation, Ohesaare borehole, $64.65 \mathrm{~m}$. figs $15-17$, lateral view, Cn 1508, $\times 40$, details of lateral surfaces of denticles $\times 600$, Kaugatuma Formation, Ohesaare borehole, $67.4 \mathrm{~m}$. figs 11, 12. Ozarkodina confluens densidentata (Viira 1983). Lateral view, Cn 1504, $\times 50$, lateral surfaces of two anterior denticles x650, Viita Beds, Ohesaare borehole, $144.05 \mathrm{~m}$. 
1971 Spathognathodus snajdri Walliser; Rexroad \& Nicoll: pl. 2, figs 4,5 .

1971 Spathognathodus snajdri Walliser; Rexroad \& Craig: 700, pl. 82 , figs $16,17$.

?1973 Spathognathodus snajdri Walliser; Pollock \& Rexroad: 83, pl. 1, figs 30-34.

1975 Spathognathodus snajdri Walliser; Helfrich: pl. 2, figs 3,7, 10-15, 17.

1976 Spathognathodus snajdri Walliser; Ebner: 20 (292), pl. 4, figs 1,2 .

1976 Ozarkodina remscheidensis snajdri Mehrtens \& Barnett (sic); Mehrtens \& Barnett: 497, pl. 1, figs 19, 22.

1980 Ozarkodina snajdri (Walliser); Chlupac et al.: pl. 25, figs 1, 4-11.

1985 Ozarkodina snajdri (Walliser); Aldridge: pl. 3.4, fig. 18. 1994 Ozarkodina snajdri (Walliser); Jeppsson et al.: fig. 4e 1995 Ozarkodina snajdri Walliser; Miller: pl. 3, figs 14-15, 17-18. 1995 Ozarkodina cf. snajdri Walliser; Miller: pl. 3, figs 13, 16.

Remarks. A new subspecies, $O$. s. parasnajdri, is described here. The holotype and all previously described material belong to the nominate subspecies $O$. s. snajdri (Walliser).

\section{Ozarkodina snajdri parasnajdri subsp. nov.}

(Pl. 3, figs 12-21, Pl. 4, figs 1-9)

Holotype. Specimen Cn 1498, Kolka Borehole 263.4 m; pl. 4, fig. 1,2 .

Type stratum. Kaugatuma Formation, Äigu Beds.

Diagnosis. Pa element with large subquadrangular basal cavity extending to posterior end of blade; denticles above cavity fused. Other elements unknown.

Description. Blade commonly long and low, with small denticles, fused above cavity; anterior end higher, posterior portion arched. Posterior termination of blade vertical or oblique concave. Basal cavity with tip a little posterior of centre of blade; lips commonly quadrangular and extending to posterior tip of blade; cavity extends as a narrow groove to anterior tip. White matter deepest above cavity, rising anteriorly and posteriorly; anterior denticles may lack white matter.

Remarks. There is variation in the length of the fused part of the blade and in the position of the basal cavity tip. However, this subspecies differs from $O$. s. snajdri in always possessing fused denticles and in the more central position of the cavity tip. The cavity lips always extend to the posterior tip of the blade.

Occurrence. Kuressaare Stage and lowermost Kaugatuma Stage: Kaugatuma borehole $28.9-45.4 \mathrm{~m}$, Ohesaare borehole 61.2 $93.4 \mathrm{~m}$, Kolka borehole $253.6-263.4 \mathrm{~m}$; Ilpla and Loode Tammik outcrops.

Material. Pa element: 84 specimens.

\section{Ozarkodina snajdri cf. snajdri (Walliser 1964)}

(P1. 1, figs 20,21)

Remarks. Seven specimens in the Ohesaare and Kolka boreholes are close to $O$. s. snajdri. All have fused denticles above the basal cavity, but on unbroken specimens the cavity can be seen to terminate just short of the posterior end of the blade.

\section{CONODONT BIOSTRATIGRAPHY OF SAAREMAA}

Samples have been processed for conodont recovery from seven boreholes and nine outcrops (Fig. 2). Spacing of samples in the

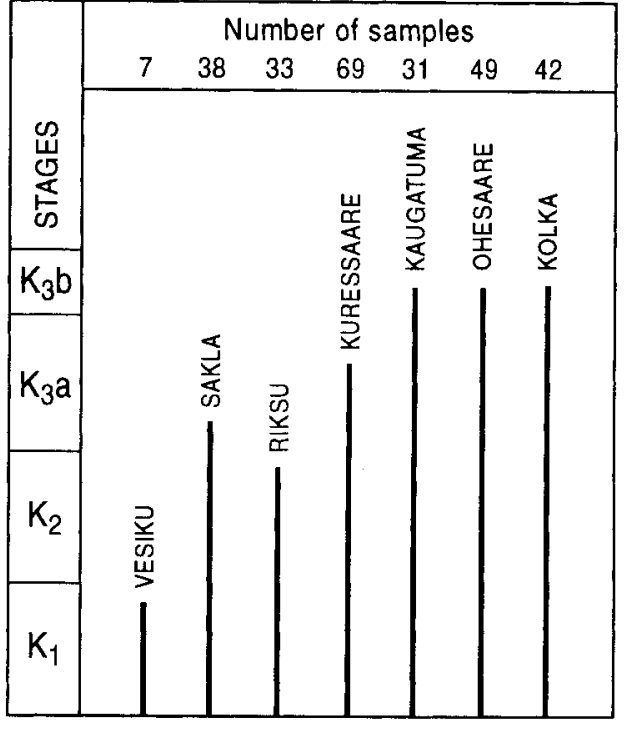

Fig. 3. Stratigraphical spans and numbers of samples for the studied boreholes.

boreholes was $1-3 \mathrm{~m}$ (Fig. 3), with a standard sample weight of $1-1.5 \mathrm{~kg}$, except in the Kuressaare (Kingissepa) borehole where weights were $c .0 .5 \mathrm{~kg}$. All samples yielded conodont elements. The distribution of members of the $O . b$. bohemica lineage is shown in Fig. 4. In addition, samples from the Rootsiküla Stage contain $O$. confluens densidentata (Viira) and Ctenognathodus murchisoni (Pander), generally in small numbers. Samples from the Paadla Stage contain $O$. confluens cornidentata (Viira), $O$. excavata (Branson and $\mathrm{Mehl}$ ), $O$. roopaensis Viira, Oulodus siluricus (Branson and Meh1), Panderodus spp. and, in the upper part, Coryssognathus dubius (Rhodes), while those from the Kuressaare Stage have $O . r$. eosteinhornensis s. 1 , $O$. confluens ambigua (Viira) and Oulodus elegans (Walliser) (Viira, $1982 a, b$, 1994).

The $O$. bohemica lineage is most completely represented in the Ohesaare borehole (Figs 5 and 6). In the lower part of the Viita Beds $O . b$. bohemica $\beta$ morph appears at a depth of $157.2 \mathrm{~m}$ and is found in seven samples through to $142.25 \mathrm{~m}$. The lineage is not represented in the succeeding $29 \mathrm{~m}$, but rare broken specimens of $O$. $s$. cf. snajdri are identified at $113.35 \mathrm{~m}$ and $106.25 \mathrm{~m}$, in the Torgu Formation of the Paadla Stage. At $100.8 \mathrm{~m}$ two specimens of $O$. crispa $\alpha_{3}$ morph occur, and a specimen of $O$. crispa $\alpha_{2}$ morph is found at $99.75 \mathrm{~m}$. In the interval $93.4-61.2 \mathrm{~m}$, seven samples contain $O$. snajdri parasnajdri. The lowest specimens are small and not well preserved, but have the widely open basal cavity characteristic of this subspecies. The largest specimens occur in the uppermost sample. The lower boundary of the Kuressaare Stage is identified by the occurrence of the thelodont Theolodus sculptilis Gross at $95.15 \mathrm{~m}$, just below the first occurrence of $O r$. eosteinhornensis at $93.40 \mathrm{~m}$.

The next borehole to the north of Ohesaare is at Kaugatuma, where Ozarkodina $b$. bohemica $\beta$ morph is represented in two samples at depths of $100.25 \mathrm{~m}$ (Viita Beds) and $81.4 \mathrm{~m}$ (Vesiku Beds). Four samples from the Paadla Stage at $49.7-69.3 \mathrm{~m}$ contain $O$. crispa $\alpha_{2}$ morph, with good typical specimens present 

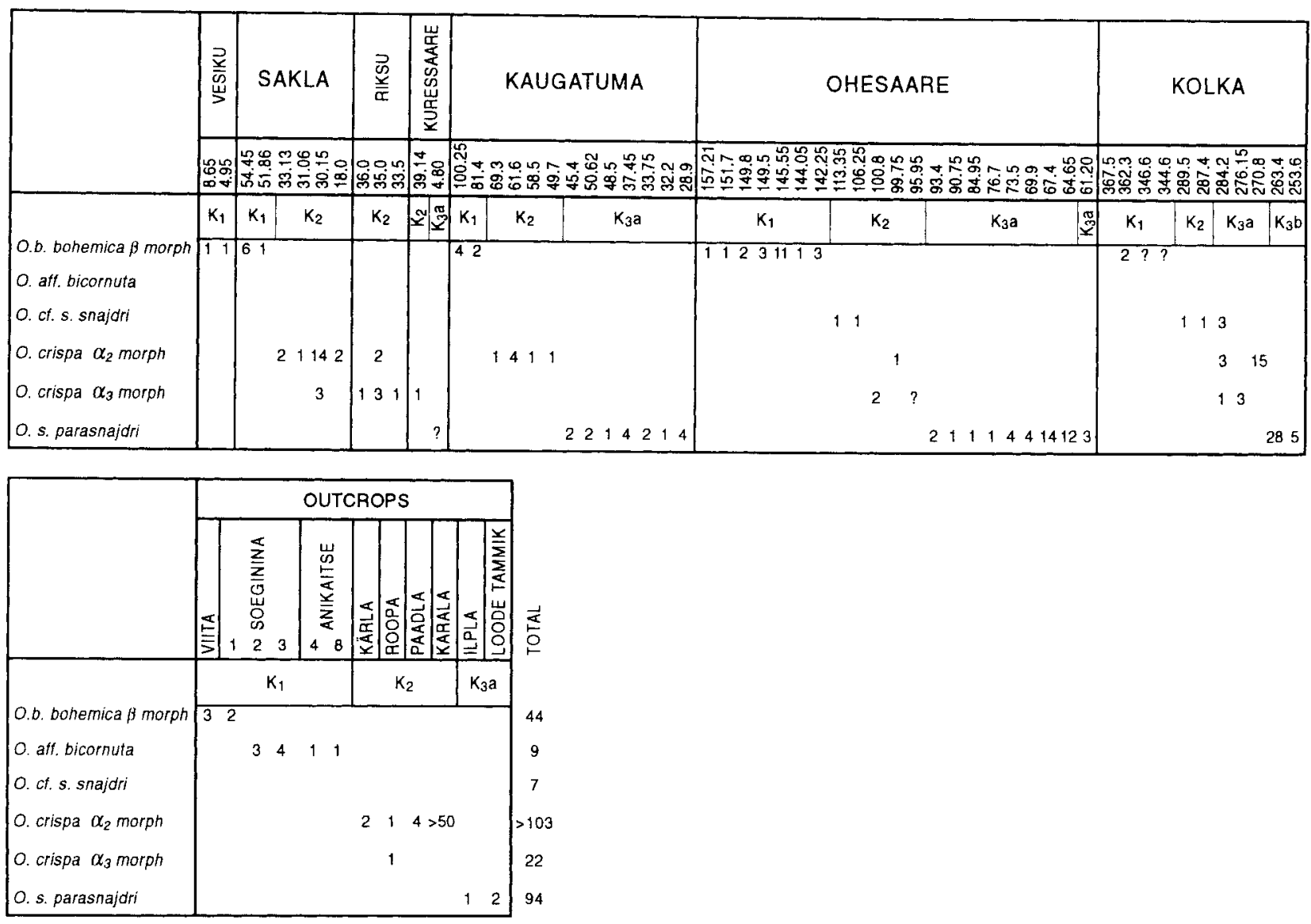

Fig. 4. Distribution of taxa in the Ozarkodina bohemica lineage on Saaremaa and northern Latvia.

in the uppermost Sauvere Beds and the Himmiste Beds. Ozarkodina s. parasnajdri occurs in the interval $28.9-45.4 \mathrm{~m}$ of the Kuressaare Stage; as noted in the Ohesaare borehole, small specimens are found in the lowest samples and the biggest specimens are from the upper samples.

In the Riksu borehole further to the north, the highest strata are assigned to the Uduvere Beds. The $O$. bohemica lineage is represented only by $O$. crispa $\alpha_{2}$ and $\alpha_{3}$ morphs at $33.5-36.0 \mathrm{~m}$ in the Sauvere Beds. The most northerly borehole sampled from West Saaremaa is at Vesiku, where $O . b$. bohemica $\beta$ morph has been recovered from two samples in the Viita and Kuusnömme Beds.

The Sakla borehole is situated in East Saaremaa, where the strata are generally dolomitized. Nevertheless, $O$. b. bohemica $\beta$ morph has been recovered from the Viita Beds and O. crispa $\alpha_{2}$ and $\alpha_{3}$ morphs occur in the Sauvere Beds and in a single sample from the Uduvere Beds (Fig. 7).

In all the boreholes, including the Kolka borehole in northernmost Latvia, $O$. b. bohemica $\beta$ morph usually occurs in the Viita Beds and occasionally also in the Kuusnömme and Vesiku Beds of the Rootsiküla Stage. All records of O. crispa on Saaremaa are in the Paadla Stage: in the Sauvere Beds of Riksu, the Sauvere and Himmiste beds of Kaugatuma, and the Torgu
Formation of Ohesaare. In the Kolka borehole, $O$. crispa occurs with $O . r$. eosteinhornensis $\mathrm{s} .1$ in the Kuressaare Stage, with the most typical specimens at a depth of $270.8 \mathrm{~m}$. In general, there is a pattern of increasingly high occurrence of $O$. crispa in the lithostratigraphical sequence from north to south, i.e. towards deeper water facies.

The exposure of Himmiste Beds or uppermost Sauvere Beds at Karala has yielded more than 50 specimens of the $\mathrm{Pa}$ element of $O$. crispa, with $\alpha_{2}$ morphs dominant, but with some $\alpha_{3}$ morphs and transitional forms (Fig. 8). A few specimens of the $\alpha_{2}$ morph have also been recovered from Kärla (Sauvere Beds) and Paadla (Himmiste Beds). One specimen from Roopa Cliff (Himmiste Beds) is identified as an $\alpha_{3}$ morph.

Small specimens with short blades and large posterior and anterior denticles have been recovered from the Soeginina cliff section (uppermost Rootsiküla Stage) of West Saaremaa and from the outcrop at Anikaitse in East Saaremaa. They are identified as $O$. aff. bicornuta. $O$. bicornuta was placed in the bohemica lineage between $O$. b. bohemica and $O$. snajdri by Helfrich (1975).

The relative completeness of the $O$. bohemica lineage in the Ohesaare borehole is complemented by evidence that Coryssognathus dubius has its longest range in this section. A more 

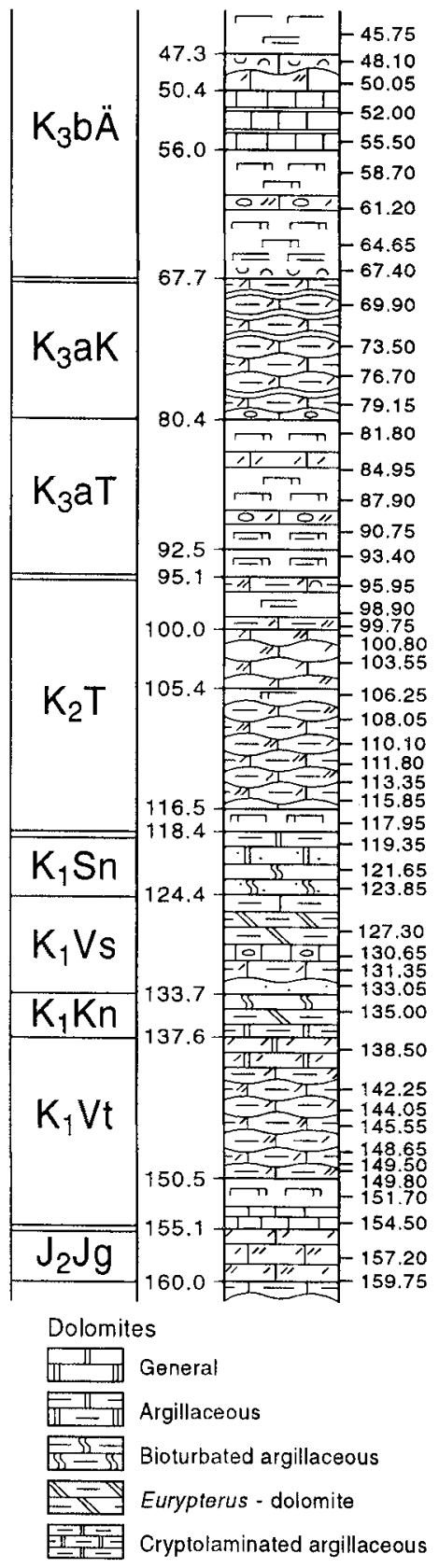
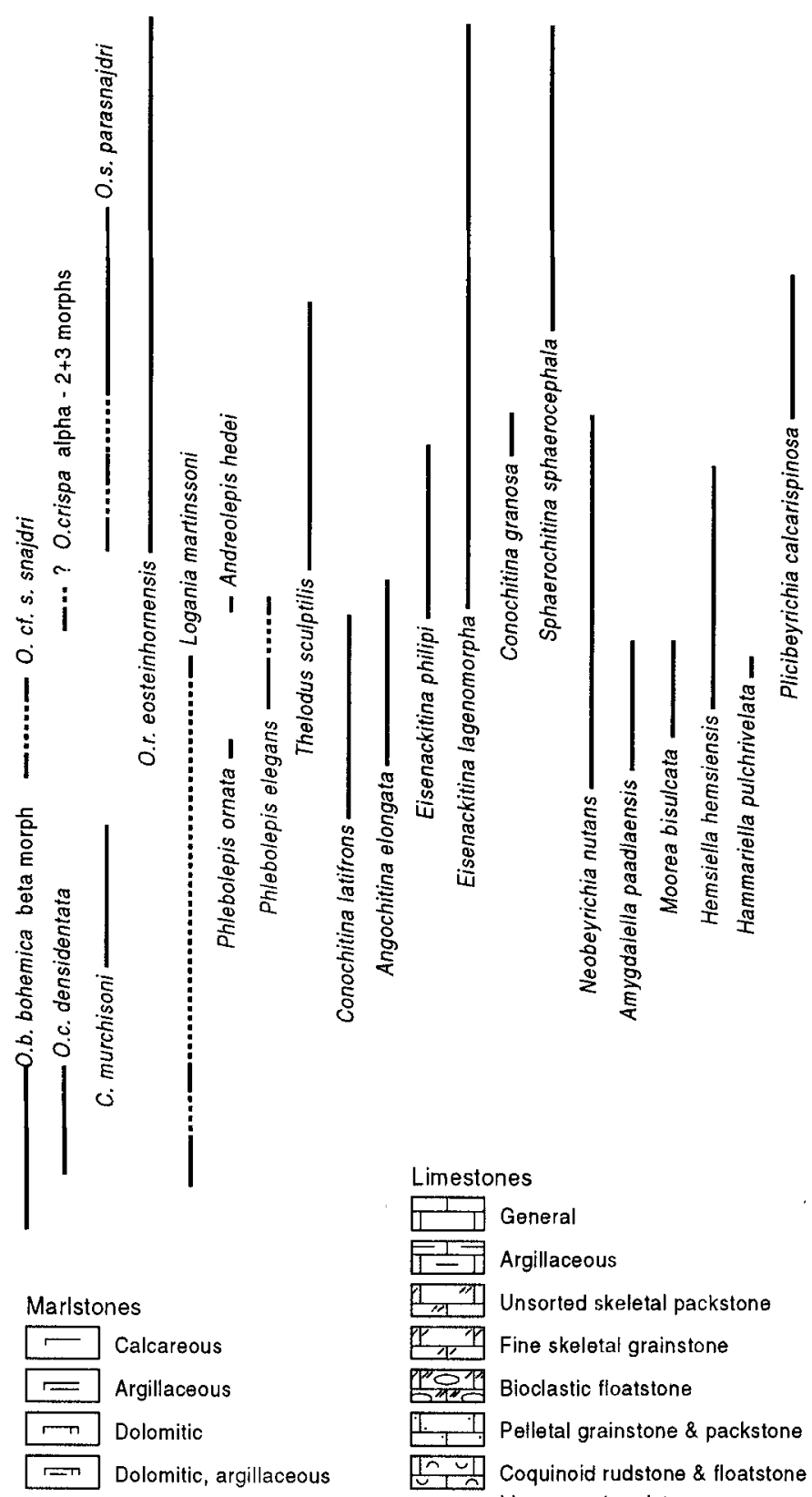

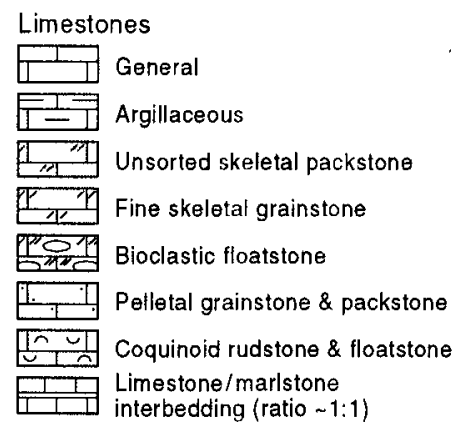

Fig. 5. Distribution of conodonts, icthyoliths (Märss, 1986), chitinozoans (Nestor, 1982) and ostracods (Sarv, 1971) in the Ohesaare borehole. $\mathrm{J}_{2} \mathrm{Jg}-$ Jaagarahu Formation, $\mathbf{K}_{1} V t$ - Viita Beds, $K_{1} \mathrm{Kn}$ - Kuusnömme Beds, $\mathbf{K}_{1} V s$ - Vesiku Beds, $\mathrm{K}_{1} \mathrm{Sn}-$ Soeginina Beds, $\mathrm{K}_{2} \mathrm{~T}-\mathrm{Torgu}$ Formation, $\mathrm{K}_{3 \mathrm{a}} \mathrm{T}$ - Tahula Beds, $\mathrm{K}_{3 \mathrm{a}} \mathrm{K}$ - Kudjape Beds, $\mathrm{K}_{3 \mathrm{~b}} \ddot{\mathrm{A}}$ - ̈̈igu Beds. Lithological column and stratigraphical divisions after Kaljo \& Nestor (1990).

complete section in this borehole than in others is also confirmed by occurrences of ichthyoliths and ostracods (Märss, 1986, 1990; Sarv, 1971)

The distribution of conodonts in the Paadla Formation, in particular, suggests the presence of gaps in the Saaremaa succession. V. Nestor (1982) has previously suggested on the basis of chitinozoan data that there is a gap between the Rootsiküla and Paadla stages, and an increase in the scale of this gap northwards has been recognized (Nestor, V., 1990; Nestor,
H., 1993). Conodont correlations with Gotland confirm a hiatus at this level (Jeppsson et al., 1994), and the absence of $O . s$. snajdri in all studied sections except Ohesaare provides consistent evidence. A break between the Paadla and Kuressaare stages was also postulated by Einasto (1991) and Märss (1992), and is corroborated by the fact that overlap between $O$. crispa and $O$. r. eosteinhornensis s. I. is apparent in the Kolka section, but has not been found anywhere on Saaremaa. Alternatively, the restricted nearshore facies represented by the Uduvere Beds 


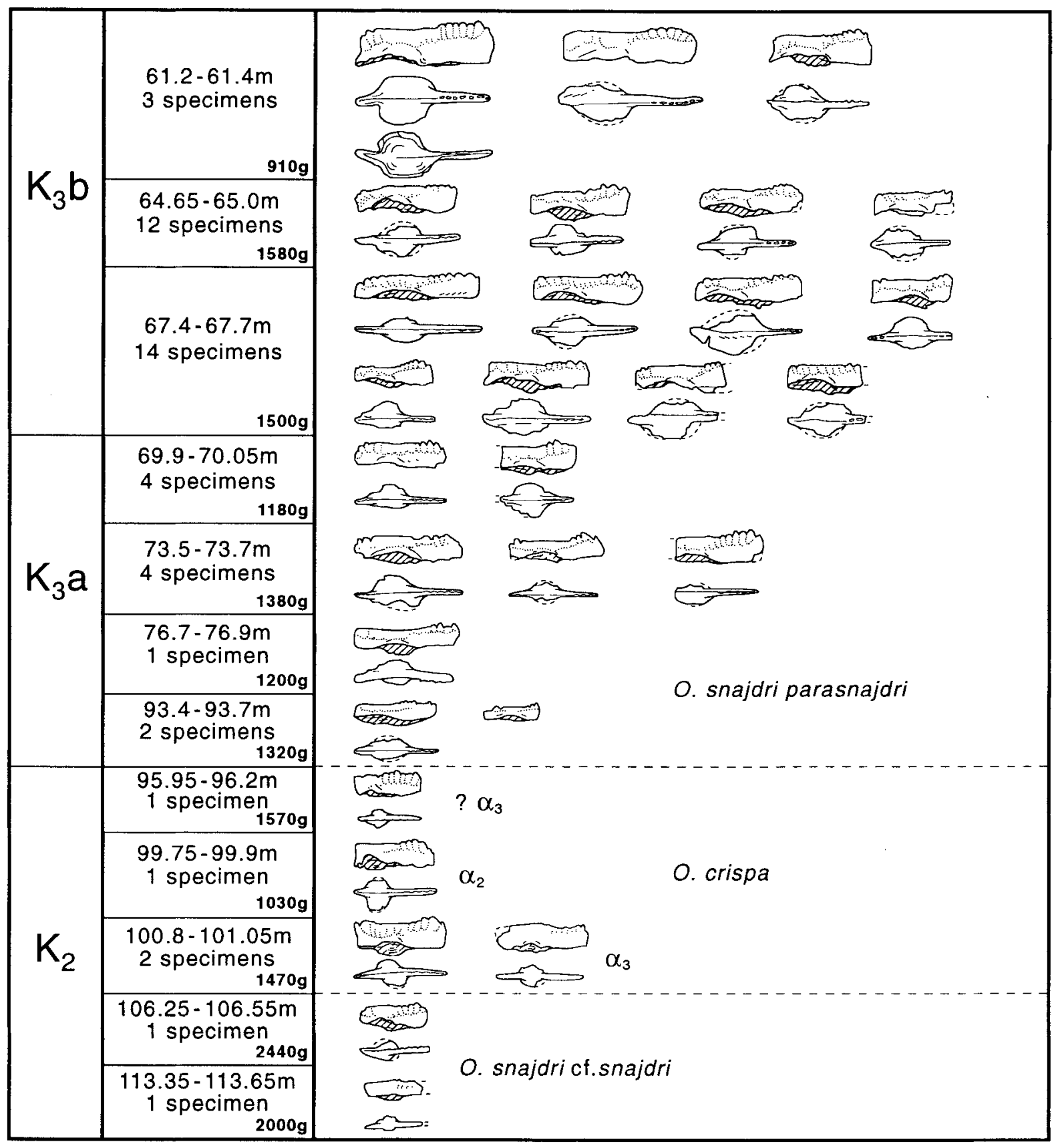

Fig. 6. Specimens of Ozarkodina snajdri cf. snajdri O. crispa $\alpha_{2}$ and $\alpha_{3}$ morphs and $O$. s. parasnajdri in the Ohesaare borehole.

may be a factor in producing the differences in the observed stratigraphical distributions of the conodonts.

\section{OTHER FOSSIL DATA}

\section{Chitinozoans}

Chitinozoans are very poorly represented in the Rootsiküla Stage, but a biozonal scheme has been developed for the Paadla and Kuressaare stages (Nestor, V., 1982, 1990). All biozonal species occur in the Ohesaare borehole (Fig. 5). Conochitina latifrons Eisenack and Angochitina elongata Eisenack appear in the lowermost Paadla Formation, and by correlation with the Ventspils borehole, Latvia, Nestor, V. (1982) deduced that strata representing the nilssoni and scanicus graptolite biozones were absent. In the Ohesaare borehole, Eisenackitina lagenomorpha (Eisenack) and E. philipi Laufeld range from the uppermost Paadla Stage into the Kuressaare Stage, with E. lagenomorpha extending much further upwards. The succeeding biozones of the Kuressaare Stage have as index species Conochitina granosa 


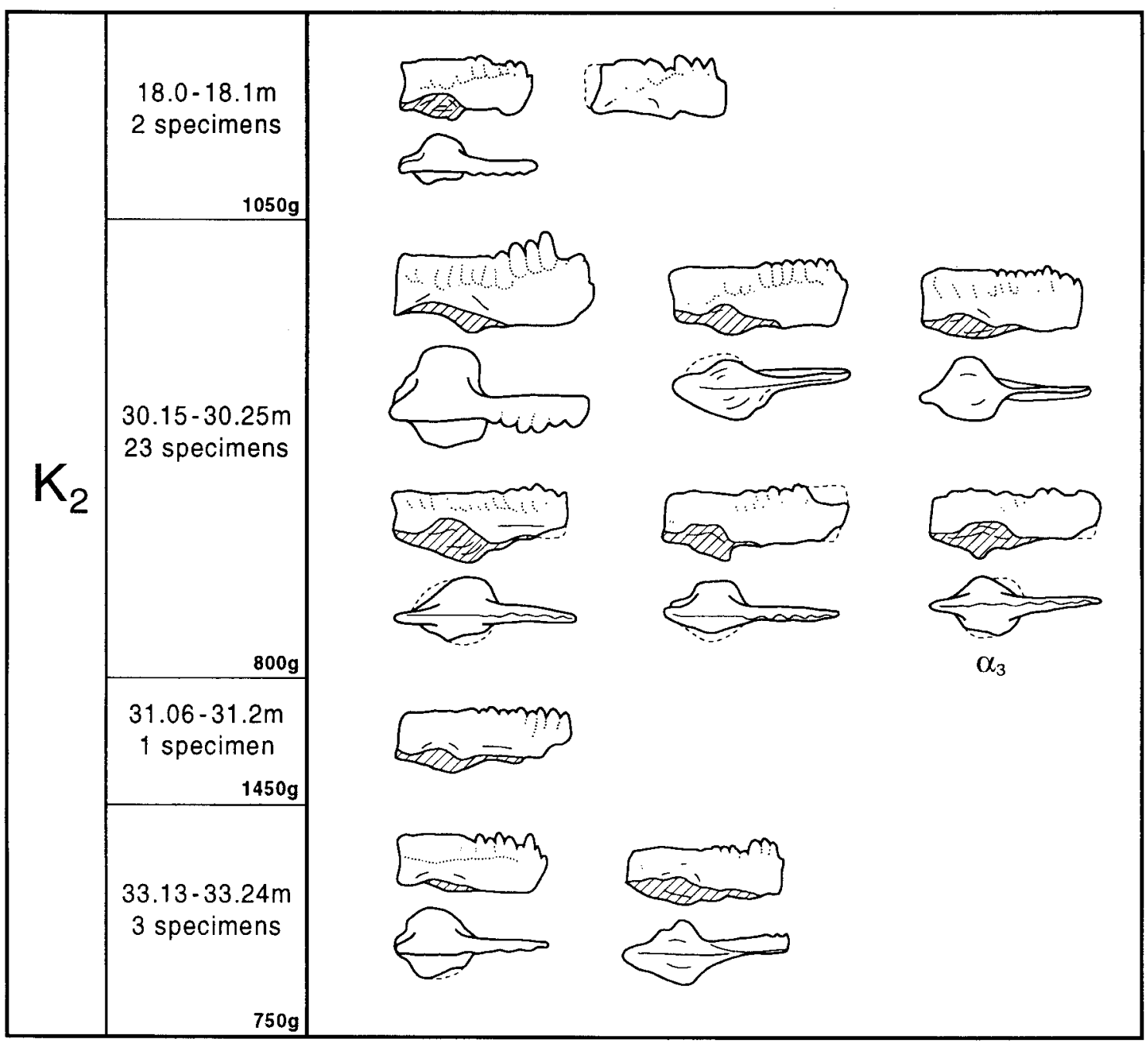

Fig. 7. Specimens of Ozarkodina crispa $\alpha_{2}$ and $\alpha_{3}$ morphs in the Sakla borehole; all except for the specimen labelled are $\alpha_{2}$ morphs.

Laufeld and Sphaerochitina sphaerocephala Eisenack.

In the Ludlow type area, Britain, C. latifrons is restricted to the Gorstian, with the highest record at the top of the Lower Bringewood Formation, while $A$. elongata occurs throughout the Gorstian from the uppermost Middle Elton Formation and extends into the Lower Leintwardine Formation (Sutherland, 1994). Sutherland (1994) also showed no overlap between the ranges of $E$. lagenomorpha and $E$. philipi, with the former spanning the Lower Bringewood Formation to Lower Leintwardine Formation and the latter ranging from the Upper Leintwardine Formation to the Upper Whitcliffe Formation. On Gotland, $C$. latifrons and $A$. elongata appear in the topmost Klinteberg Beds, and E. lagenomorpha and E. philipi appear together in the upper part of the Hemse Beds coincident with the highest occurrence of C. latifrons (Laufeld, 1974).

\section{Ostracods}

The distribution of ostracods in the Ohesaare borehole has been documented by Sarv (1971), and the ranges of key species are shown in Fig. 5. Ostracods are rare in the Rootsiküla Stage and absent from the lowermost Paadla Stage, but in the Paadla Stage above a depth of $115 \mathrm{~m}$, rich assemblages occur. Sarv (1971) reported that five species, including Neobeyrichia nutans Martinsson, had not been found in the northern East Baltic other than in the Ohesaare borehole, but included a N. nutans biozone in the upper Paadla Stage of Saaremaa (Sarv, 1982). In Britain, $N$. nutans occurs in the Lower Leintwardine Formation (Siveter, 1989), but other species recorded in the Ohesaare borehole are not represented.

\section{Ichthyoliths}

A microvertebrate biozonation for the Silurian of the northern East Baltic has been established by Märss (1982, 1990), and all the zonal species for the Rootsiküla, Paadla and Kuressaare stages are represented in the Ohesaare borehole (Märss, 1986; see Fig. 5). Logania martinssoni (Gross) occurs in the Rootsiküla and lowermost Paadla stages, and has also been found in the Halla, Mulde, Klinteberg and Hemse beds of Gotland (Fred- 


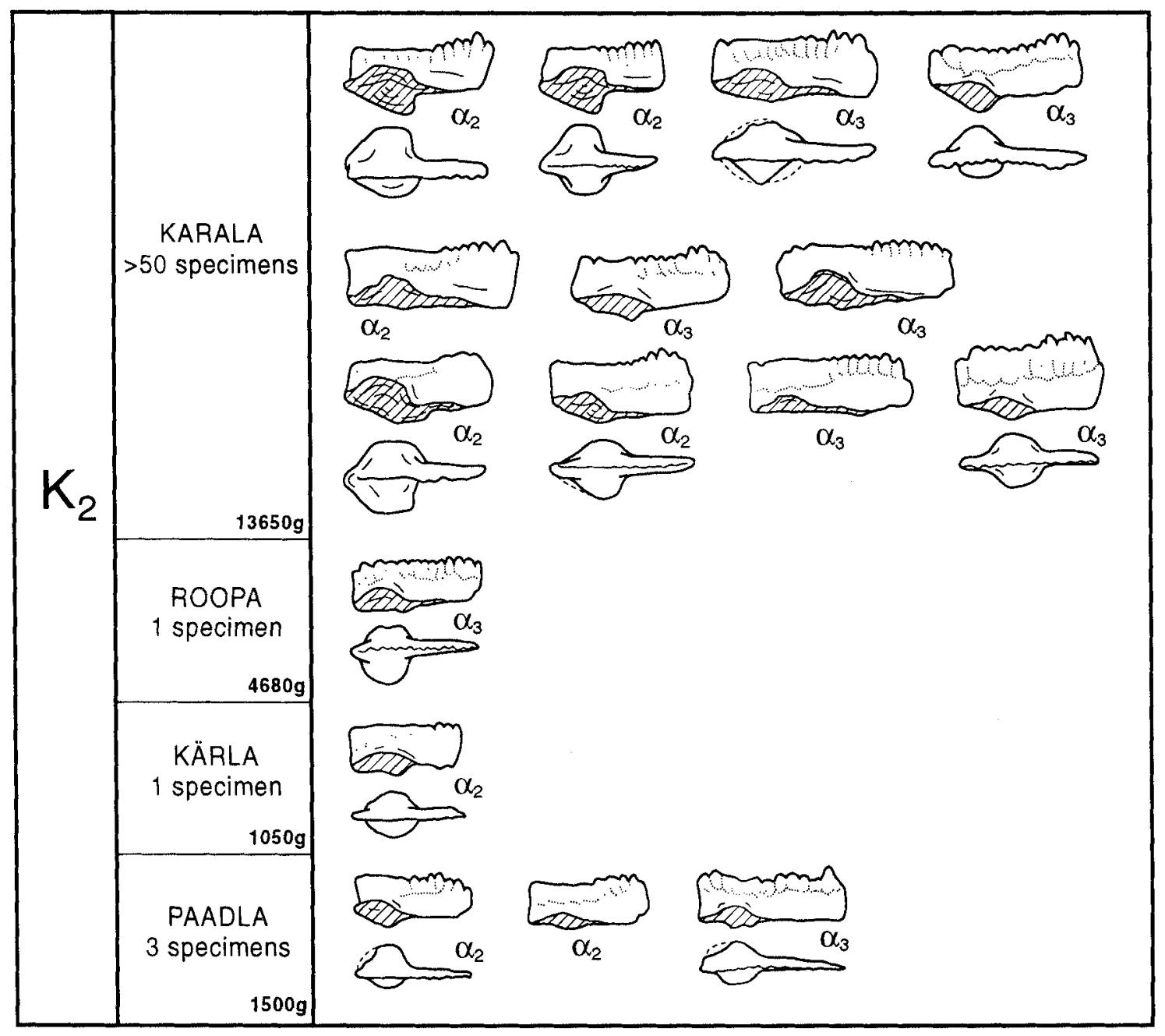

Fig. 8. Specimens of Ozarkodina crispa $\alpha_{2}$ and $\alpha_{3}$ morphs in the Karala, Roopa, Kärla and Paadla outcrops.

holm, 1990). Phlebolepis ornata Märss characterizes strata assigned to the upper Sauvere Beds by Märss (1986); this species has not been found in the other boreholes, but occurs in the lower Hemse Beds on Gotland (Fredholm, 1988). Phlebolepis elegans Pander ranges from the upper Sauvere Beds to the lowermost Uduvere Beds, and has been recorded widely in Estonia and Latvia. Andreolepis hedei Gross is restricted to the Uduvere Beds, and is also known from the upper Hemse Beds on Gotland (Fredholm, 1988, 1989) and the Long Quarry Beds (lowermost Prídolí) of South Wales (Märss, 1982).

\section{CORRELATION}

The evidence given by conodonts, chitinozoans and icthyoliths for correlations is not always consistent. An attempt to provide the most parsimonious correlation between the succession on Saaremaa and those of the Ludlow type area and of Gotland is shown in Fig. 9. The correlation with Gotland is based on the recent conodont work by Jeppsson et al. (1994), who confirmed the presence of gaps in the exposed Saaremaa sequence. One of these gaps is between the Jaagarahu and Rootsiküla stages, embracing strata referred to the upper Slite Beds, Mulde Beds and Halla Beds on Gotland. This results in only part of the $O . b$. bohemica Biozone being recognized on Saaremaa, here characterized by the $\beta$ morph.

The gap between the Rootsiküla and Paadla stages on Saaremaa corresponds to the uppermost Klinteberg Beds and lower Hemse Beds of Gotland (Jeppsson et al., 1994). Chitinozoan evidence, particularly the presence of $C$. latifrons in the Ohesaare borehole, indicates that at least the upper part of the Gorstian Stage is represented on Saaremaa; the occurrence of Phlebolepis ornata is consistent with this. The hiatus is probably of greater significance in shallower facies away from Ohesaare, where $P$. ornata has not been found, and Kaljo (1990, p. 26) has suggested that the entire Gorstian may be lacking in the shoreward region. The conodont $O$. s. cf. snajdri and the ostracod $N$. nutans have also been found only in the Ohesaare borehole.

Jeppsson et al. (1994) also determined the presence of a gap between the Paadla and Kuressaare stages, equivalent to the upper Hemse and Eke beds of Gotland. Part of the evidence for 


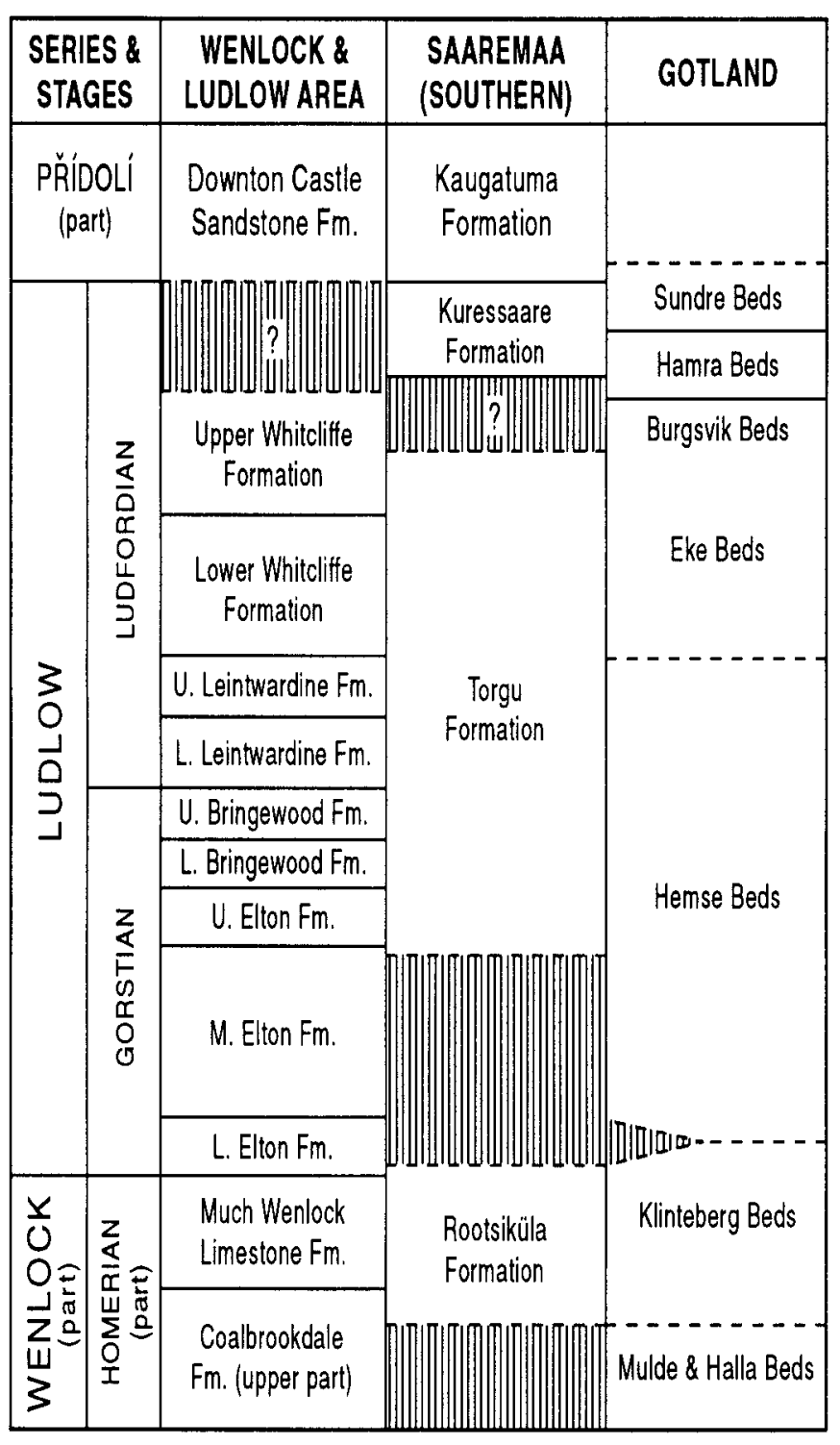

Fig. 9. Correlation of the upper Wenlock to lower Prídolí sequences of Britain (Wenlock Edge and Ludlow area), Estonia (southern Saaremaa) and Gotland.

this is the absence of Polygnathoides siluricus Walliser on Saaremaa, although this species is rare in most facies and its distribution may have been environmentally controlled. However, there is a marked change in conodonts at the Paadla/ Kuressaare boundary on Saaremaa, with $C$. dubius, O. excavata and $O$. crispa disappearing, and a fauna characterized by $O . r$. eosteinhornensis, s. 1., O. confluens, Oulodus elegans (Walliser) and $O$. snajdri parasnajdri appearing.

Uppermost Ludlow and lowermost Downton conodont faunas from the Welsh Borderland have recently been documented in detail by Miller (1995). He noted that the top of the Upper Whitcliffe Formation in the Ludlow area is characterized by $C$. dubius and $O$. s. snajdri, with less common $O$. r. eosteinhornensis and $O$. cf. crispa. At Ludlow itself, $O$. cf. crispa rnges $30-15 \mathrm{~cm}$ below the top of the formation; the specimens compare with the $\alpha_{3}$ morph described in this paper and found in the upper Paadla Stage on Saaremaa. Miller (1995), however, also recovered $O$. crispa from the lower part of the Whitcliffe Formation at Tite's Point, Gloucestershire, and from the lower part of the Upper Perton Beds at Woolhope; these specimens have a narrow furrow on the upper surface and are similar to the $\beta$ morph of Walliser \& Wang (1989).

There is a problem in using the appearance of $O$. crispa in correlating the Saaremaa succession with that of the type Ludlow, as the species is found throughout the upper Sauvere Beds, the Himmiste Beds and the Uduvere Beds. This part of the sequence is usually correlated with the middle part of the Ludlow Series. A revision of this correlation would contradict the evidence from the thelodont $P$. elegans, which has been found by RJA in the Upper Bringewood Formation of the Welsh Borderland, but co-occurs with $O$. crispa in the Sakla Borehole. An explanation may be that the fluctuating nearshore environment of Saaremaa was suited to the earlier evolution of populations of $O$. crispa, which spread into the Welsh Borderland with the onset of appropriate conditions. Further stratigraphical evidence, perhaps from acritarchs or from chemostratigraphy, is required to clarify this question.

The base of the Prídolí Series is commonly identified by the appearance of the ostracod Frostiella groenvalliana Martinsson (Hansch \& Siveter, 1994), which occurs in the basal Downton Castle Sandstone Formation of Ludlow (Bassett et al., 1982; Miller, 1995) and in the lower part of the Kaugatuma Stage on Saaremaa (Sarv, 1982). However, the conodont fauna of the Kuressaare Stage suggests a Prídolí age, or at least an age postdating the highest Upper Whitcliffe Formation at Ludlow. One explanation that fits all the fossil data would be the existence of a gap in the succession at Ludlow at the top of the Upper Whitcliffe Formation, as intimated by Jeppsson (1983, p. 137), equivalent to the Kuressaare Stage of Estonia and encompassing the highest part of the Ludlow Series. Bassett et al. (1982, p. 6), however, while noting that the basal contact of the Downton Castle Sandstone Formation is sharp and scoured, considered there to be no indication of a major break in sedimentation at this level.

\section{ACKNOWLEDGEMENTS}

We are grateful for funding from the Royal Society, which permitted V.V. to make two visits to Britain to complete this work. The manuscript was greatly improved by comments from Prof. D. Kaljo, Dr C. G. Miller and Dr L. Jeppsson.

\section{APPENDIX: Locality information}

Ohesaare borehole - situated in the southern part of the Ohesaare cliff, on the west coast of the Sörve Peninsula.

Kaugatuma borehole - situated near Kaugatuma cliff on the west coast of the Sörve Peninsula.

Riksu borehole-Situated near Riksu lake, Riksu village, southwest Saaremaa.

Vesiku borehole - situated near the mouth of Vesiku brook, westernmost Saaremaa.

Kuressaare (Kingissepa) borehole - situated in the centre of Kuressaare (in the yard of the restaurant 'Tuulik').

Sakla borehole - situated on the south side of Sakla village, 
southeast Saaremaa.

Kolka borehole - situated south of Kola village, on the east coast of the Kola cape, northernmost Kuseme Peninsula, Latvia. Anikaitse - small cliff $(2.7 \mathrm{~m})$ on the coast of the Kübassaare Peninsula, Anikaitse cape, easternmost Saaremaa.

Ilpla-outcrop on the shore terrace, western part of Ilpla village, south Saaremaa.

Karala - small old quarry at the west end of Karala village, westernmost Saaremaa.

Kärla - outcrop in Kärla brook, central Kärla village, westernmost Saaremaa.

Loode Tammik - small old quarry $(1.2 \mathrm{~m})$ in Loode Oak Wood (Tammik), $2 \mathrm{~km}$ west of Kuressaare, south Saaremaa.

Paadla - old quarry $(1.8 \mathrm{~m})$ in Paadla village, $50 \mathrm{~m}$ south of the Kuressaare-Kihelkonna road, central Saaremaa.

Roopa - small cliff $(1.5 \mathrm{~m})$ on the southernmost cape of the Atla Peninsula, western coast of Saaremaa.

Soeginina - cliff $(4.2 \mathrm{~m})$ on the south-west shore of the Atla Peninsula, westernmost Saaremaa.

Viita - old trench on the shore at Rootsiküla village, $2 \mathrm{~km}$ southwest of Kihelkonna, western Saaremaa.

\section{Manuscript received May 1995 \\ Manuscript accepted July 1996}

\section{REFERENCES}

Aldridge, R. J. 1975a. The stratigraphic distribution of conodonts in the British Silurian. Journal of the Geological Society of London, 131: 607618.

Aldridge, R. J. 1975b. The Silurian conodont Ozarkodina sagitta and its value in correlation. Palaeontology, 18: 323-332.

Aldridge, R. J., Dorning, K. J. \& Siveter, D. J. 1981. Distribution of microfossil groups across the Wenlock shelf of the Welsh Basin. In Neale, J. W. \& Brasier, M. D. (Eds), Microfossils from Recent and Fossil Shelf Seas, 18-30. Ellis Horwood, Chichester, for British Micropalaeontological Society.

Aldridge, R. J. 1985. Conodonts of the Silurian System from the British Isles. In Higgins, A. C. \& Austin, R. L. (Eds), A Stratigraphical Index of Conodonts, 68-92, 238-241. Ellis Horwood, Chichester, for British Micropalaeontological Society.

Aldridge, R. J. \& Schönlaub, H. P. 1989. Conodonts. In Holland, C. H. \& Bassett, M. G. (Eds), A Global Standard for the Silurian System, 274-279. National Museum of Wales, Cardiff.

An Tai-xiang, 1987. The Lower Paleozoic Conodonts of South China. Beijing University Publishing House, 238 pp.

Austin, R. L. \& Bassett, M. G. 1967. A sagitta zone conodont fauna from the Wenlockian of the Usk Inlier, Monmouthshire. Geological Magazine, 104: 274-283.

Balogh, K. \& Kozur, H. 1985. The Silurian and Devonian in the surroundings of Nekézseny (southernmost Uppony Mts, northern Hungary). Acta Mineralogica-Petrographica, Szeged., 27: 193-205.

Barrick, J. E. \& Klapper, G. 1976. Multielement Silurian (late Llandoverian-Wenlockian) conodonts of the Clarita Formation, Arbuckle Mountains, Oklahoma, and phylogeny of Kockelella. Geologica et Palaeontologica, 10: 59-100.

Bassett, M. G., Kaljo, D. \& Teller, L. 1989. The Baltic region. In Holland, C. H. \& Bassett, M. G. (Eds), A Global Standard for the Silurian System, 274-279. National Museum of Wales, Cardiff.

Bassett, M. G., Lawson, J. D. \& White, D. E. 1982. The Downton Series as the fourth Series of the Silurian System. Lethaia, 15: 1-24.

Boogaard, M. van den, 1990. A Ludlow conodont fauna from Irian Jaya (Indonesia). Scripta Geologica, 92: 1-27.

Branson, E. B. \& Mehl, M. G. 1933. Conodonts from the Bainbridge (Silurian) of Missouri. The University of Missouri Studies, 8: 39-52.

Bultynck, P. \& Pelhate, A. 1971. Découverte de la zone a eosteinhor- nensis (conodontes) dans le synclinorium médian du Massif Armoricain. Memoires Bureau de Recherches geologiques et Minières, 73: 189-197.

Chlupác, Kríz, J. \& Schönlaub, H. P. 1980. Silurian and Devonian localities of the Barrandian. In Schönlaub, H. P. (Ed.), Second European Conodont Symposium - ECOS II, Abhandlungen der Geologischen Bundesanstalt, Wien, 35: 147-180.

Cooper, B. J. 1977. Upper Silurian conodonts from the Yarrangobilly Limestone, southeastern New South Wales. Royal Society of Victoria Proceedings, 89: 183-191.

De Deckker, P. 1976. Late Silurian (Late Ludlovian) conodonts from the Kildrummie Formation, South of Rockley, New South Wales. Journal and Proceedings, Royal Society of New South Wales, 109: 59-69.

Denkler, K. E. \& Harris, A. G. 1988. Homeognathodus peniculus (Conodonta), a new earliest Pridolian index species, and the Ludlovian-Pridolian boundary in the Central Appalachian Basin. U.S. Geological Survey Bulletin 1837: C.1-8, pl. 1.

Drygant, D. M. 1971. Conodont Spathognathodus crispus Zone in Skala Stage (Silurian of Volyno-Podolia). [In Ukrainian with English abstract.] Proceedings of the Academy of Sciences, Ukraine SSR, 5: $780-783$.

Drygant, D. M. 1984. Silurian and Lower Devonian conodonts of VolynoPodolia [In Russian]. Naukova Dymka, Kiev, 191 pp.

Dzik, J. 1976. Remarks on the evolution of Ordovician conodonts. Acta Palaeontologica Polonica, 21: 395-453.

Ebner, F. 1976. Das Silur/Devon-Vorkommen von Eggenfeld - ein Beitrag zur Biostratigraphie des Grazer Paläozoikums. Mitteilungen der Abteilung für Bergbau, Geologie und Paläontologie des LandesMuseums Joanneum, 37: 275-305.

Einasto, R. 1991. Silurian. In Puura, V., Kalm, V. \& Puura, J. (Eds), First World Meeting of Estonian Geologists, Tallinn-Lohusalu, 9-14 September 1991. Geology and Mineral Resources of Estonia: Excursion Guide, 7-9. Tallinn

Fåhraeus, L. E. 1969. Conodont zones in the Ludlovian of Gotland and a correlation with Great Britain. Sveriges Geologiska Undersökning, C63(2), 1-33.

Feist, R. \& Schönlaub, H. P. 1974. Zur Silur/Devon-Grenze in der östlichen Montagne Noire Süd-Frankreichs. Neues Jahrbuch fur Geologie und Palèntologie Monatshefte, 1974, 200-219.

Flajs, G. 1967. Conodontenstratigraphische Untersuchungen im Raum von Eisenerz, Nördliche Grauwackenzone. Mitteilungen der Geologischen Gesellschaft in Wien, 59: 157-212.

Fredholm, D. 1988. Vertebrate biostratigraphy of the Ludlovian Hemse Beds of Gotland, Sweden. Geologiska Föreningens $i$ Stockholm Förhandlingar, 110: 237-253.

Fredholm, D. 1989. Silurian vertebrates of Gotland, Sweden. Lund Publications in Geology, 76, $47 \mathrm{pp}$.

Fredholm, D. 1990. Agnathan vertebrates in the Lower Silurian of Gotland, Sweden. Geologiska Föreningens i Stockholm Förhandlingar, 112: 61-84.

Hansch, W. \& Siveter, D. J. 1994. 'Nodibeyrichia jurassica' and associated beyrichiacean ostracode species and their significance for the correlation of late Silurian strata in the Baltic and Britain. Journal of Micropalaeontology, 13: 81-91.

Hass, W. H. 1959. Conodonts from the Chappel Limestone of Texas. U.S. Geological Survey Professional Paper 294-J: 365-400.

Helfrich, C. T. 1975 [dated 1974]. Silurian Conodonts from the Wills Mountain Anticline, Virginia, West Virginia and Maryland. Geological Society of America Special Paper, 161.

Jeppsson, L. 1983. Silurian conodont faunas from Gotland. Fossils and Strata, 15: 121-144.

Jeppsson, L., Aldridge, R. J. \& Dorning, K. J. 1995. Wenlock (Silurian) oceanic episodes and events. Journal of the Geological Society, London, 152: $487-498$.

Jeppsson, L., Viira, V. \& Männik, P. 1994. Silurian conodont-based correlations between Gotland (Sweden) and Saaremaa (Estonia). Geological Magazine, 131: 201-218.

Jiang Wu, Zhang Fang, Zhou Xiyun, Xiong Jianfei, Dai Jinyie \& Zhong Duan. 1986. Conodonts-Palaeontology [in Chinese]. Southwestern Petroleum Institute, $287 \mathrm{pp}$.

Kaljo, D. (Ed.) 1970. The Silurian of Estonia [in Russian with English abstracts]. Tallinn, Valgus, $343 \mathrm{pp}$. 
Kaljo, D. (Ed.) 1977. Facies and Fauna of Baltic Silurian [in Russian with English abstracts]. Academy of Sciences of the Estonian SSR, Tallinn, $286 \mathrm{pp}$.

Kaljo, D. 1990. The Silurian of Estonia. In Kaljo, D. \& Nestor, H. (Eds), Field Meeting Estonia 1990, an Excursion Guidebook, 21-26. Estonian Academy of Sciences, Tallinn.

Kaljo, D. \& Klaamann, E. (Eds) 1982a. Communities and Biozones in the Baltic Silurian [in Russian with English abstracts]. Tallinn, Valgus, $139 \mathrm{pp}$.

Kaljo, D. \& Klaamann, E. (Eds) 1982b. Ecostratigraphy of the East Baltic Silurian. Tallinn, Valgus, $112 \mathrm{pp}$

Kaljo, D. \& Nestor, H. (Eds), Field Meeting Estonia 1990, an Excursion Guidebook. Estonian Academy of Sciences, Tallinn, $209 \mathrm{pp}$.

Klapper, G. \& Murphy, M. A. 1974. Silurian-Lower Devonian Conodont sequence in the Roberts Mountains Formation of Central Nevada. University of California Publications in Geological Sciences, 111.

Kleffner, M. A. 1990. Wenlockian (Silurian) conodont biostratigraphy, depositional environments, and depositional history along the eastern flank of the Cincinnati Arch in Southern Ohio. Journal of Paleontology, 64: 319-328.

Kozur, H. 1984. Preliminary report about the Silurian to Middle Devonian sequences near Nekézseny (southernmost Uppony Mts., northern Hungary). Geologische und Paläontologische Mitteilungen Innsbruck, 13: 149-176.

Kríz, J., Dufka, P., Jaeger, H. \& Schönlaub, H. P. 1993. The Wenlock/ Ludlow boundary in the Prague Basin. Jahrbuch der Geologischen Bundesanstalt, 136: 809-839.

Laufeld, S. 1974. Silurian Chitinozoa from Gotland. Fossils and Strata, 5: $130 \mathrm{pp}$.

Link, A. G. \& Druce, E. C. 1972. Ludlovian and Gedinnian Conodont Stratigraphy of the Yass Basin, New South Wales. Bulletin of the Bureau of Mineral Resources, Geology and Geophysics, Australia, 134

Männik, P. \& Viira, V. 1990. Conodonts. In Kaljo, D. \& Nestor, H. (Eds), Field Meeting Estonia 1990, an Excursion Guidebook, 84-89. Estonian Academy of Sciences, Tallinn.

Märss, T. 1982. Vertebrate zones in the East Baltic Silurian. In Kaljo, D. \& Klaamann, E. (Eds), Ecostratigraphy of the East Baltic Silurian, 97106. Tallinn, Valgus.

Märss, T. 1986. Silurian Vertebrates of Estonia and West Latvia [in Russian with English summary]. Tallinn, Valgus, $104 \mathrm{pp}$.

Märss, T. 1990. Vertebrates. In Kaljo, D. \& Nestor, H. (Eds), Field Meeting Estonia 1990, an Excursion Guidebook, 93-96. Estonian Academy of Sciences, Tallinn.

Märss, T. 1992. Vertebrate history in the Late Silurian. Proceedings of the Estonian Academy of Science, Geology, 44: 205-214.

Mehrtens, C. J. \& Barnett, S. G. 1976. Conodont subspecies from the Upper Silurian-Lower Devonian of Czechoslovakia. Micropaleontology, 22: 491-500.

Meidla, T. \& Sarv, L. Ostracodes. In Kaljo, D. \& Nestor, H. (Eds), Field Meeting Estonia 1990, an Excursion Guidebook, 68-71. Estonian Academy of Sciences, Tallinn.

Miller, C. G. 1995. Ostracode and conodont distribution across the Ludlow/Pridolí boundary of Wales and the Welsh Borderland. Palaeontology, 38: 341-384.

Miller, C. G. \& Aldridge, R. J. 1997. Ozarkodina remscheidensis plexus conodonts from the upper Ludlow and lower Prídoli of the Welsh Borderland and Wales. Journal of Micropalaeontology, 16, 41-49.

Nestor, H. 1993. Catalogue of Silurian stratigraphic units and stratotypes in Estonia and Latvia. Estonian Academy of Sciences, Tallinn, 23pp.

Nestor, H. \& Einasto, R. 1977. Facies-sedimentary model of the Silurian Paleobaltic sedimentary basin. In Kaljo, D. (Ed.), Silurian Facies and Fauna of East Baltic, 89-121. Academy of Sciences of the Estonian SSR Institute of Geology, Tallinn [in Russian with English abstract]
Nestor, V. 1982. Correlation of the East Baltic and Gotland Silurian by chitinozoans. In Kaljo, D. and Klaamann, E. (Eds). Ecostratigraphy of the East Baltic Silurian, 89-95. Academy of Sciences of the Estonian SSR Institute of Geology, Tallinn.

Nestor, V. 1990. Silurian chitinozoans. In Kaljo, D. \& Nestor, H. (Eds), Field Meeting Estonia 1990, an Excursion Guidebook, 80-83. Estonian Academy of Sciences, Tallinn.

Pollock, C. A. \& Rexroad, C. B. 1973. Conodonts from the Salina Formation and the upper part of the Wabash Formation (Silurian) in north-central Indiana. Geologica et Palaeontologica, 7: 77-92.

Qiu Hong-rong 1985. Silurian conodonts in Xizang (Tibet). Bulletin of the Institute of Geology of the Chinese Academy of Geological Sciences, Beijing, 11: 23-36. [in Chinese, with English abstract].

Rexroad, C. B. \& Craig, W. W. 1971. Restudy of conodonts from the Bainbridge Formation (Silurian) at Lithium, Missouri. Journal of Paleontology, 45: 684-703

Rexroad, C. B. \& Nicoll, R. S. 1971. Summary of conodont biostratigraphy of the Silurian System of North America. In Sweet, W. C. \& Bergström, S. M. (Eds), Symposium on Conodont Biostratigraphy. Geological Society of America Memoir, 127: 207-225.

Sarv, L. 1971. Silurian ostracodes in the Ohesaare boring. Proceedings of the Academy of Sciences, Estonian SSR, Chemistry Geology, 20: 349355. [in Russian with English abstract].

Sarv, L. 1982. On ostracode zonation of the East Baltic Upper Silurian. In Kaljo, D. and Klaamann, E. (Eds). Ecostratigraphy of the East Baltic Silurian, 71-77. Academy of Sciences of the Estonian SSR Institute of Geology, Tallinn.

Schmidt, F. 1858. Untersuchungen über die silurische Formation von Ehstland, Nord-Livland und Oesel. Archiv fur die Naturkunde Liv-, Est- und Kurlands. Dorpat, Ser. 1, $248 \mathrm{pp}$.

Schönlaub, H. P. 1969. Das Paläozoikum zwischen Bischofalm und Hohem Trieb (Zentrale Karnische Alpen). Jahrbuch der Geologischen Bundesanstalt, Wien, 112: 265-320.

Siveter, D. J. 1989. Ostracodes. In Holland, C. H. \& Bassett, M. G. (Eds), A Global Standard for the Silurian System, 252-264. National Museum of Wales, Cardiff.

Sutherland, S. J. E. 1994. Ludlow chitinozoans from the type area and adjacent regions. Palaeontographical Society Monograph, 148(594): 1104.

Viira, V. 1982a. Shallow water conodont Ctenognathodus murchisoni (Late Wenlock, Estonia). In Kaljo, D. and Klaamann, E. (Eds), Communities and Biozones in the Baltic Silurian, 63-83. Tallin, Valgus [in Russian with English abstract].

Viira, V. 1982b. Late Silurian shallow and deep water conodonts from the East Baltic. In Kaljo, D. and Klaamann, E. (Eds), Ecostratigraphy of the East Baltic Silurian, 79-87. Academy of Sciences of the Estonian SSR Institute of Geology, Tallinn.

Viira, V. 1994. A new Upper Silurian conodont species from Estonia. Proceedings of the Estonian Academy of Science, Geology, 43: 32-37.

Walliser, O. H. 1964. Conodonten des Silurs. Abhandlungen des Hessischen Landesamtes für Bodenforschung, 41: 106 pp.

Walliser, O. H. 1971. Conodont biostratigraphy of the Silurian of Europe. In Sweet, W. C. \& Bergström, S, M. (Eds), Symposium on Conodont Biostratigraphy. Geological Society of America Memoir, 127: 195-206.

Walliser, O. H. \& Wang, C.-y. 1989. Upper Silurian Stratigraphy and conodonts from the Quijing District, East Yunnan, China. Courier Forschungsinstitut Senckenberg, 110: 111-121.

Wang, C.-y. 1980. Upper Silurian conodonts from Quijing District, Yunnan [in Chinese with English summary]. Acta Palaeontologica Sinica, 19: 369-378.

$\mathrm{Yu}$ Hongin 1985. Conodont biostratigraphy of Middle-Upper Silurian from Xainza, Northern Xizang (Tibet). Contribution to the Geology of the Qinghai-Xizang (Tibet) Plateau, 16: 15-31. [in Chinese with English abstract]. 